Portland State University

PDXScholar

\title{
Planning Ahead for Livable Communities Along the Powell-Division BRT: Neighborhood Conditions and Change
}

\author{
Lisa K. Bates \\ Portland State University, Ikbates@pdx.edu \\ Aaron Golub \\ Portland State University \\ Devin Macarthur \\ Portland State University \\ Seyoung Sung \\ Portland State University
}

Follow this and additional works at: https://pdxscholar.library.pdx.edu/trec_reports

Part of the Transportation Commons, Urban Studies Commons, and the Urban Studies and Planning Commons

Let us know how access to this document benefits you.

\section{Recommended Citation}

Bates, L., Golub, A., Macarthur, D., Sung, S. Planning Ahead for Livable Communities Along the PowellDivision BRT: Neighborhood Conditions and Change. NITC-RR-912. Portland, OR: Transportation Research and Education Center (TREC), 2017. https://doi.org/10.15760/trec.179

This Report is brought to you for free and open access. It has been accepted for inclusion in TREC Final Reports by an authorized administrator of PDXScholar. Please contact us if we can make this document more accessible: pdxscholar@pdx.edu. 


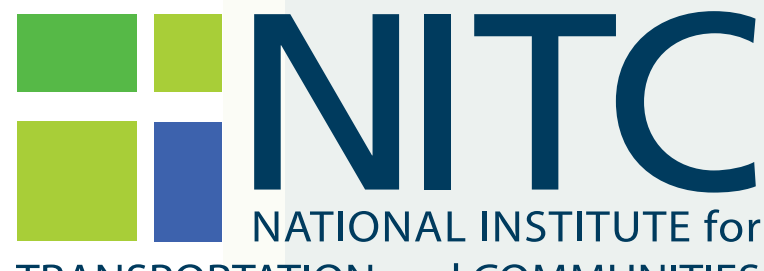

TRANSPORTATION and COMMUNITIES

FINAL REPORT

Planning Ahead for Livable Communities along the Powell-Division Bus Rapid Transit: Neighborhood Conditions and Change

NITC-RR-912 घuly 2017

NITC is a U.S. Department of Transportation

national university transportation center.

HI! TREC 



\title{
PLANNING AHEAD FOR LIVABLE COMMUNITIES ALONG THE POWELL-DIVISION BUS RAPID TRANSIT: NEIGHBORHOOD CONDITIONS AND CHANGE
}

\author{
Final Report
}

NITC-RR-912

by

Lisa K. Bates, principal investigator

Aaron Golub, co-principal investigator

Graduate research assistants:

Devin Macarthur and Seyoung Sung

Nohad A. Toulan School of Urban Studies and Planning

Portland State University

for

National Institute for Transportation and Communities (NITC)

P.O. Box 751

Portland, OR 97207
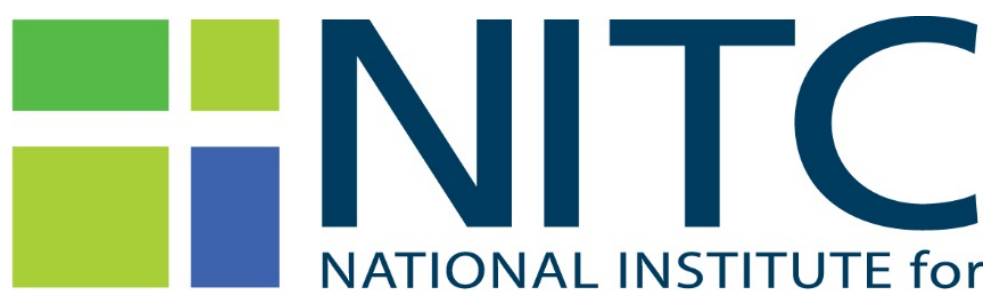

TRANSPORTATION and COMMUNITIES

July 2017 


\begin{tabular}{|c|c|c|c|c|}
\hline \multicolumn{5}{|c|}{ Technical Report Documentation Page } \\
\hline $\begin{array}{l}\text { 1. Report No. } \\
\text { NITC } 912\end{array}$ & \multicolumn{3}{|l|}{ 2. Government Accession No. } & 3. Recipient's Catalog No. \\
\hline \multirow{2}{*}{\multicolumn{3}{|c|}{$\begin{array}{l}\text { 4. Title and Subtitle } \\
\text { Planning Ahead for Livable Communities along the Powell-Division Bus Rapid Transit: } \\
\text { Neighborhood Conditions and Change }\end{array}$}} & \multicolumn{2}{|c|}{$\begin{array}{l}\text { 5. Report Date } \\
\text { July } 2017\end{array}$} \\
\hline & & & \multicolumn{2}{|c|}{ 6. Performing Organization Code } \\
\hline \multicolumn{3}{|c|}{$\begin{array}{l}\text { 7. Author(s) } \\
\text { Lisa K. Bates and Aaron Golub }\end{array}$} & \multicolumn{2}{|c|}{ 8. Performing Organization Report No. } \\
\hline \multirow{2}{*}{\multicolumn{3}{|c|}{$\begin{array}{l}\text { 9. Performing Organization Name and Address } \\
\text { Nohad A. Toulan School of Urban Studies and Planning } \\
\text { Portland State University }\end{array}$}} & \multicolumn{2}{|c|}{ 10. Work Unit No. (TRAIS) } \\
\hline & & & \multicolumn{2}{|c|}{ 11. 912} \\
\hline \multirow{2}{*}{\multicolumn{3}{|c|}{$\begin{array}{l}\text { 12. Sponsoring Agency Name and Address } \\
\text { National Institute for Transportation and Communities (NITC) } \\
\text { P.O. Box } 751 \\
\text { Portland, Oregon } 97207\end{array}$}} & \multicolumn{2}{|c|}{$\begin{array}{l}\text { 13. Type of Report and Period Covered } \\
\text { 08.01.2015-12.31.2016 }\end{array}$} \\
\hline & & & \multicolumn{2}{|c|}{ 14. Sponsoring Agency Code } \\
\hline \multicolumn{5}{|c|}{ 15. Supplementary Notes } \\
\hline \multicolumn{5}{|c|}{$\begin{array}{l}\text { New transit investments can be a double-edged sword for disadvantaged communities (e.g., those included in environmental justice and Title } \\
\text { VI protected classes). Transit investments improve communities' mobility and access, and may improve health with reduced driving. However, } \\
\text { there is also the potential for transit-oriented development (TOD) to spur gentrification and displacement if affordable housing is lost. } \\
\text { Understanding transit corridor conditions and change with new infrastructure is important for learning how to mitigate negative effects and } \\
\text { support inclusive communities with access to transit for lower-income households. The planning of a new bus rapid transit line along the } \\
\text { Powell-Division corridor in Portland-Gresham provides an opportunity to understand neighborhood impacts of transit investment and evaluate } \\
\text { programs designed to preserve and create affordable housing; include residents in economic development on the corridor; and build livable } \\
\text { communities in an underserved area of the region. This proposal is for a research partnership between Toulan School of Urban Studies and } \\
\text { Planning faculty and the Portland Bureau of Planning and Sustainability to evaluate current conditions and potential for impacts of TOD, and } \\
\text { to build a long-term program of assessment of neighborhood change and program evaluation as the city pilots new approaches to equitable } \\
\text { TOD. The first phase will document the potential costs to communities if an integrated approach to livable communities were not taken, by } \\
\text { assessing the risk of housing loss and displacement. DOT priorities are developing, evaluating and disseminating a coordinated approach to } \\
\text { livable communities that includes housing and transportation. This work will speak to the scholarly debates about gentrification and public } \\
\text { infrastructure investment, and will be presented to practitioner audiences through venues such as New Partners for Smart Growth, the } \\
\text { PolicyLink think tank, and other learning opportunities for professionals. }\end{array}$} \\
\hline \multicolumn{2}{|c|}{$\begin{array}{l}\text { 17. Key Words } \\
\text { Equity, housing, affordability, accessibility, bus rapid transit, transportation } \\
\text { planning, displacement }\end{array}$} & \multicolumn{3}{|c|}{$\begin{array}{l}\text { 18. Distribution Statement } \\
\text { No restrictions. Copies available from OTREC: } \\
\text { www.otrec.us }\end{array}$} \\
\hline $\begin{array}{l}\text { 19. Security Classif } \\
\text { Unclassified }\end{array}$ & $\begin{array}{l}\text { 20. Security Classification (of } \\
\text { Unclassified }\end{array}$ & age) & $\begin{array}{l}\text { 21. No. of Pages } \\
58\end{array}$ & 22. Price \\
\hline
\end{tabular}




\section{ACKNOWLEDGEMENTS}

This project was funded by the National Institute for Transportation and Communities (NITC) in conjunction with the City of Portland's Bureau of Planning and Sustainability.

\section{DISCLAIMER}

The contents of this report reflect the views of the authors, who are solely responsible for the facts and the accuracy of the material and information presented herein. This document is disseminated under the sponsorship of the U.S. Department of Transportation University Transportation Centers Program and the City of Portland in the interest of information exchange. The U.S. Government and the City of Portland assume no liability for the contents or use thereof. The contents do not necessarily reflect the official views of the U.S. Government and the City of Portland. This report does not constitute a standard, specification, or regulation.

\section{RECOMMENDED CITATION}

Bates, Lisa K., Aaron Golub, Devin Macarthur and Seyoung Sung. Planning Ahead for Livable Communities along the Powell-Division Bus Rapid Transit: Neighborhood Conditions and Change. NITC-RR-912. Portland, OR: Transportation Research and Education Center (TREC), 2017. 


\section{TABLE OF CONTENTS}

EXECUTIVE SUMMARY .......................................................................................... 1

1.0 INTRODUCTION...................................................................................................... 2

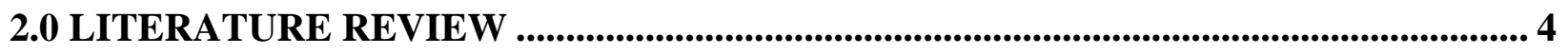

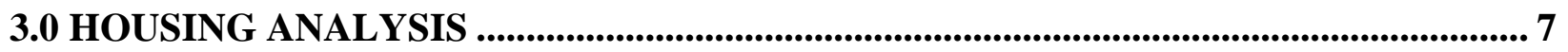

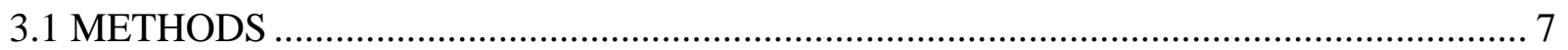

3.1.1 Geographic units ....................................................................................... 7

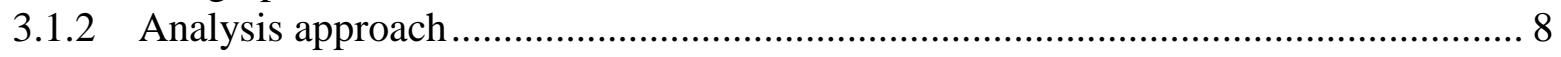

3.1.2.1 Household vulnerability to housing issues ....................................................... 8

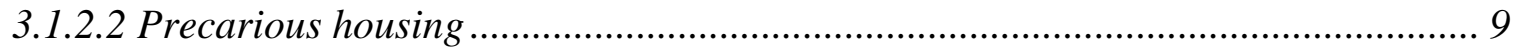

3.1.2.3 Neighborhood conditions and change during BRT planning .............................. 11

3.2 RESULTS: HOUSING ALONG THE POWELL-DIVISION CORRIDOR IS

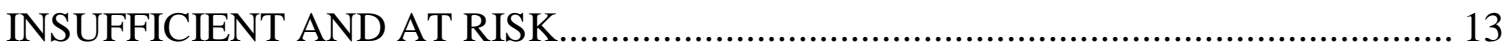

3.2.1 Household vulnerability to housing issues ......................................................... 13

3.2.2 Housing cost burden .................................................................................... 16

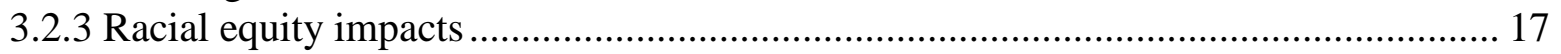

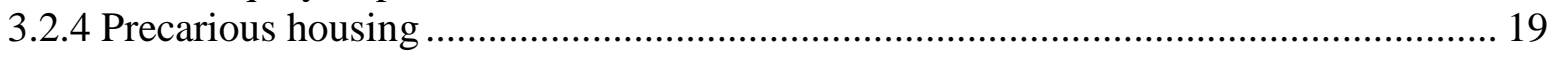

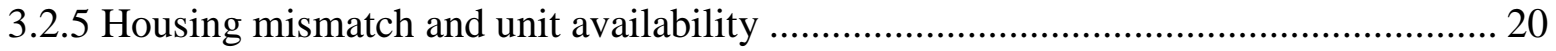

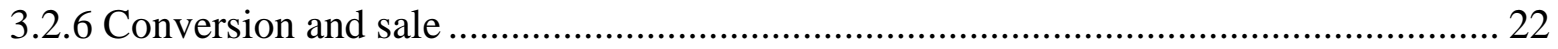

3.3 CONCLUSIONS: NEIGHBORHOOD CONDITIONS AND CHANGE DURING BRT

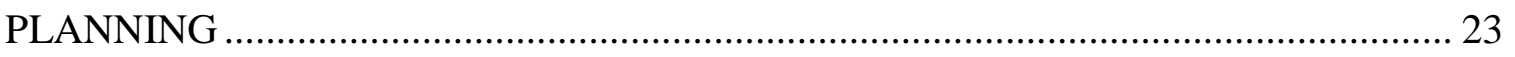

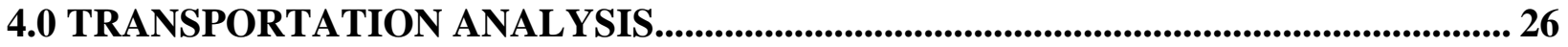

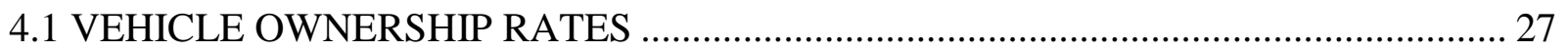

4.2 TRAVEL MODE CHOICE IN THE CORRIDOR .................................................... 27

4.3 JOB LOCATIONS AND TRIP PATTERNS OF CORRIDOR WORKERS AND

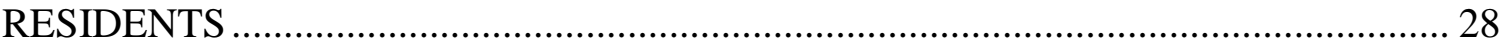

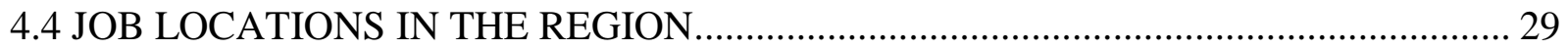

4.5 JOB LOCATIONS FOR THOSE LIVING ALONG THE CORRIDOR ........................ 29

4.6 HOME LOCATIONS FOR THOSE WORKING ALONG THE CORRIDOR................ 30

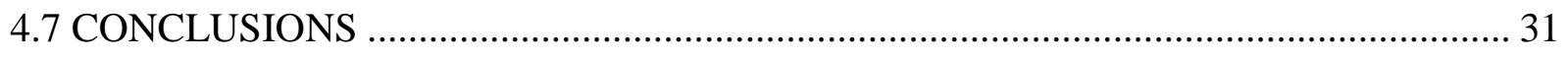

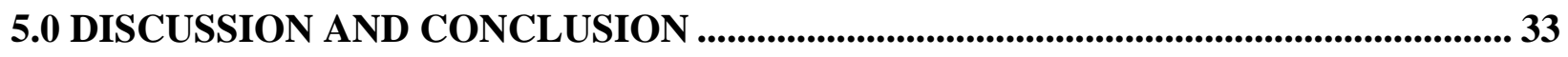

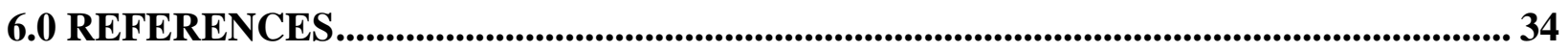

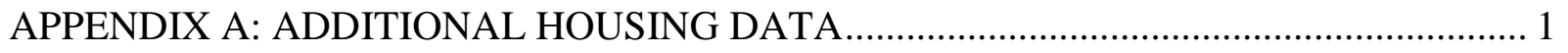

APPENDIX B: ADDITIONAL TRANSPORTATION DATA ............................................ 3 


\section{LIST OF TABLES}

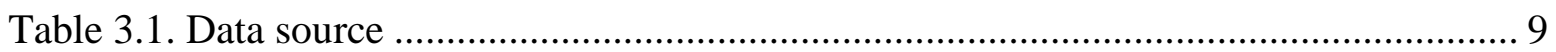

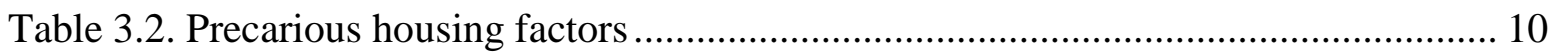

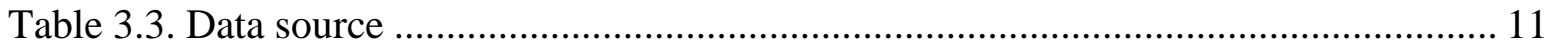

Table 3.4. Typology methodology and data sources ..................................................... 12

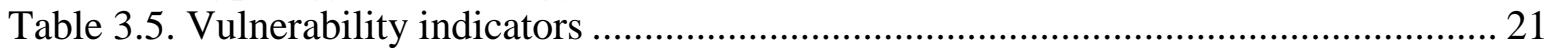

Table 3.6. Renter: Large family by income level ...................................................... 22

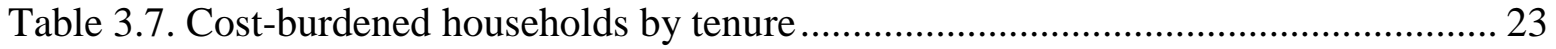

Table 3.8. Cost-burdened households with low income (<80\% AMFI) ............................. 23

Table 3.9. Cost-burdened households by race/ethnicity ................................................ 24

Table 3.10. Precarious housing indicators .................................................................. 25

Table 3.11. Affordable housing stock.................................................................. 26

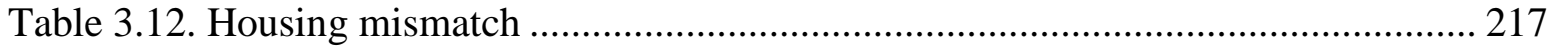

Table 4.1. Average number of vehicles per household................................................ 32

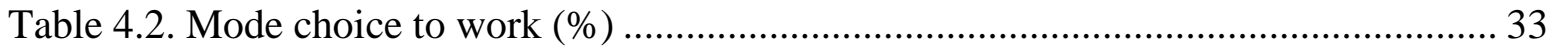

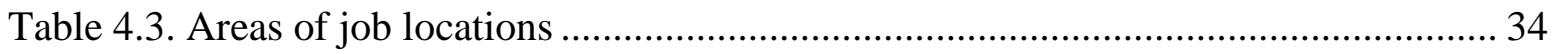

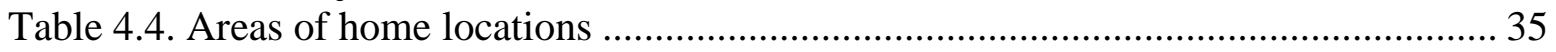

\section{APPENDIX A}

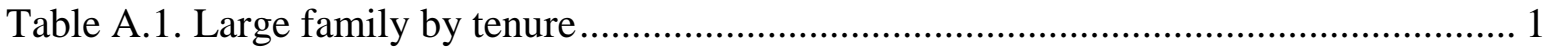

Table A.2. Owner: Large family by income level ....................................................... 1

Table A.3. Cost-burdened owner households breakdown ................................................ 2

Table A.4. Cost-burdened renter households breakdown ................................................ 2

Table A.5. The drilldown of multifamily buildings..................................................... 3 


\section{LIST OF FIGURES}

Figure 3.1. Original proposed segments along the corridor by Metro (2014) ..................... 15

Figure 3.2. Segments along the corridor in the analysis ............................................... 15

Figure 3.3. Multifamily buildings sold 2011-2016 in corridor ....................................... 22

Figure 3.4. 2010 gentrification stage with rent index increases from 2010-2015 ............... 24

Figure 3.5. 2010 gentrification stage with sales price index increases from 2010-2015..... 24

\section{APPENDIX B}

Figure B.1. Vehicle ownership rates along the corridor ................................................. 3

Figure B.2. Job locations for low- and high-income workers......................................... 4

Figure B.3. Job locations for workers living in Central Eastside .................................... 5

Figure B.4. Job locations for workers living in East Portland .......................................... 6

Figure B.5. Job locations of workers living in west Gresham ..................................... 7

Figure B.6. Job locations of workers living in central Gresham ................................... 8

Figure B.7. Home locations of workers working in Central Eastside .............................. 9

Figure B.8. Home locations of workers working in East Portland .................................. 10

Figure B.9. Home locations of workers working in west Gresham .................................. 11

Figure B.10. Home locations of workers working in central Gresham ........................... 12 



\section{EXECUTIVE SUMMARY}

New transit service is often sold as attracting development and increasing property values. As transit changes the accessibility of an area, it becomes more attractive for investment. Transit investment leverages development investment of greater than \$1 per \$1 of transit investment (Hook et al., 2013). The existing literature suggests that new transit investments can create serious affordable housing problems for the very residents who depend most on transit: lowerincome households and people of color (Dawkins and Moeckel, 2014). Public investments sometimes even just the announcement of a planned investment - increase the investment potential of a neighborhood (Golub et al., 2011). A challenge for considering whether a new bus rapid transit (BRT) system will have substantial neighborhood gentrification effects is that most research on this topic is about fixed rail, and there are fewer BRT systems in the U.S.

The context for this project is the planning of new BRT infrastructure in East Portland, crossing several neighborhoods in different stages of gentrification and some with disproportionately poor residents. Residents and equity advocates were deeply concerned about both the potential to improve transit access in neighborhoods not well connected to service, and also about the possibility that new infrastructure would displace residents from their housing.

This project links up the intended and unintended costs and benefits of new transit investments in diverse communities, particularly those already understood to house many vulnerable populations and to have a high potential for gentrification. We expect that this analysis can help improve our understanding of the transportation access and housing impacts of a new BRT system. As policymakers and scholars increasingly are concerned with equity in transit-oriented development, we can debate whether "the problem" is transportation or housing; this research allows for an assessment of the contribution of individual household demographics and housing status, neighborhood location and market conditions to outcomes. For both transit and housing questions, we ask: How does the new transit service differentially affect specific populations of equity concern? How does the new transit service differentially affect residents of neighborhoods across a spectrum of gentrification risk? How does the new transit service differentially affect these populations depending on which kinds of neighborhoods they live in?

We approach this analysis from a cumulative impacts standpoint: It is impossible to understand the specific and marginal impacts of the BRT investment on housing and transportation. The improvements in service, the impacts on property markets and rents, and the resulting equity issues from this investment are small compared to the overall dynamics of gentrification and displacement affecting hundreds of households each month. We think this is defensible as it is in the public interest and in the purview of the agencies involved, including Metro and the city of Portland, trying to not worsen an ongoing crisis of housing affordability, displacement and gentrification. Therefore, we zoom out to understand the overall dynamics in the corridor. We do this to ask if there are policy and investment decisions, which can be used and leveraged as part of the project to stabilize the corridor. 


\subsection{INTRODUCTION}

This project links up the intended and unintended costs and benefits of new transit investments in diverse communities, particularly those already understood to house many vulnerable populations and to have a high potential for gentrification. We expect that this analysis can help improve our understanding of the transportation access and housing impacts of a new bus rapid transit (BRT) system. The research will be able to speak to specific populations of concern (low income, low educational attainment, people of color, immigrants, renters); to a range of neighborhood market conditions (from early stages of gentrification to no real estate pressures/needing revitalization); and it will address how those factors interact for households living along the planned BRT route. As policymakers and scholars increasingly are concerned with equity in transit-oriented development (TOD), we can debate whether "the problem" is transportation or housing; this research will allow for an assessment of the contribution of individual household demographics and housing status, neighborhood location and market conditions to outcomes. For both transit and housing questions, we will ask:

- How does the new transit service differentially affect specific populations of equity concern?

- How does the new transit service differentially affect residents of neighborhoods across a spectrum of gentrification risk?

- How does the new transit service differentially affect these populations depending on which kinds of neighborhoods they live in?

Philosophically, we approach this analysis of housing and transportation development dynamics from a cumulative impact standpoint: It is impossible to understand the specific and marginal impacts of the BRT investment on housing and transportation. The improvements in service, the impacts on property markets and rents, and the resulting equity issues from this investment are small compared to the overall dynamics of gentrification and displacement affecting hundreds of households each month. Therefore, we approach this project by looking at housing and access dynamics in the corridor overall without attempting to piece out or model the specific impact of the investment. We think this is defensible as it is in the public interest and in the purview of the agencies involved, including Metro and the city of Portland, trying to not worsen an ongoing crisis of housing affordability, displacement and gentrification. Therefore, we zoom out to understand the overall dynamics in the corridor. We do this to ask if there are policy and investment decisions, which can be used and leveraged as part of the project to stabilize the corridor. We know that understanding the negative impacts of the project, and mitigating them, are a responsibility of the planning agencies under the National Environmental Policy Act (NEPA), the Civil Rights Act (Title VI) and Executive Order 12898 on environmental justice (EPA, 2016).

We hope to go further here, and situate this investment within a larger context of urban change. It is the responsibility of the planning agencies to leverage the significant federal 
investment in this corridor for the improvement of the community regardless of the specific connection of those processes to this investment. Thus, we take a cumulative impact approach to better understand a history of transformation in the corridor, rather than a snapshot of just the last period due to a small investment.

Indeed a similar approach was taken recently in a landmark case in Lexington, KY, where a road investment was to displace a group of low-income households from the project area (FHWA, 2016). In this case, while routine compensation would have sufficed, a longer-term and more macroscopic analysis showed that decades of divestment and isolation, and uncertainty concerning the road project, had negatively impacted the property values of households in the area. Therefore, merely compensating them would have been possibly legal, but would have ignored the potential to leverage project resources to benefit households, which have long suffered due to a lack of investment in the corridor. The project put its energy into instituting a land trust model to develop affordable housing close to the existing community, allowing most of the existing residents to relocate together into a new, and affordable, location. The land trust and housing investment was part of the mitigation process for the road project - not an afterthought and not a project pushed off onto another agency for another day. What was clear from this example is that a cumulative impact approach was found legal and defensible and leveraged resources from the project to extend into the housing and neighborhood cohesion impacts it would've had. While the project impacts for Powell-Division are somewhat different, we contend that a broader view can be quite fruitful and more realistically understands the project impacts in the context of the changing corridor.

In this project we hope to highlight the importance of existing, naturally occurring, affordable housing in the corridor. We also hope to highlight the importance of the improvements in access for low-wage workers, which will be created by the investment. Together, we think this will show a heightened urgency about the importance of preserving existing, naturally occurring, affordable housing and the imperative to create new opportunities for affordable housing along the corridor. Recent policy statements by U.S. Secretary of Transportation Anthony Foxx highlight the importance of leveraging transportation investments for improving access to opportunity in increasingly unequal regions (Foxx, 2016). This project could be an important tool in improving regional equality and part of the solution to connect lowincome populations moving further east to the opportunity-rich inner Portland area. Not creating new affordable housing opportunities, and ignoring the impact on existing affordable housing in the corridor, would be a sad outcome of a major regional investment in transportation improvements. We hope this report will highlight the significant housing needs in the corridor and the kinds of travel that will be improved through the investment.

We begin the report with an overview of existing scholarship about the interaction between transportation investments and housing and affordability. There is some concern that improvements in transportation will cause real estate price and rent appreciation and further displace low-income households. We then move to an analysis of housing needs and impacts as well as an analysis of current transportation needs among low-income workers. We finish with some conclusions about the corridor and the impacts of the BRT investment. 


\subsection{LITERATURE REVIEW}

New transit service is often sold as attracting development and increasing property values. As transit changes the accessibility of an area, it becomes more attractive for investment. Transit investment leverages development investment of greater than \$1 per \$1 of transit investment (Hook et al., 2013). Nelson and Ganning (in progress) connect bus rapid transit (BRT) investment with increased jobs and property values. Of course, transit also improves mobility and access for residents in transit-oriented development (TOD), providing more access to jobs and needed services. TOD can reverse the isolation of poverty and contribute to climate change improvements - if affordable housing is included (Gauthier, 2014). Indeed, new transit investments can be a double-edged sword for disadvantaged communities (e.g., those included in environmental justice and Title VI protected classes). However, there is also the potential for TOD to spur gentrification and displacement if affordable housing is lost due to new investment and new residents with higher incomes. Understanding transit corridor conditions and change with new infrastructure is important for learning how to mitigate negative effects and support inclusive communities with access to transit for lower-income households.

The existing literature suggests that new transit investments can create serious affordable housing problems for the very residents who depend most on transit: lower-income households and people of color (Dawkins and Moeckel, 2014). Public investments - sometimes even just the announcement of a planned investment - increase the investment potential of a neighborhood (Golub et al., 2011). When the city signals its commitment to placemaking in a particular neighborhood through improvements to the built environment and development incentives, it decreases the risk of investment. The private market will respond by making capital available and increasing development activities. Additionally, as the public sector improves neighborhood access, infrastructure and amenities, the neighborhood becomes more desirable and demand to live there by higher-income households increases. When public investments are made in neighborhoods where markets are already heating up, it can increase the intensity of the change and exacerbate displacement. Studies in the Bay Area found involuntary displacement due to the construction of new rail stations as rent premiums were charged for transit access. Chapple (2009) found that gentrifying neighborhoods were twice as likely to be near transit.

Gentrification in TODs has a wide range of consequences. First, decreased neighborhood diversity can have a number of negative impacts as concentrated poverty increases in a region both for regional economic health and for families' social and economic futures. Involuntary housing displacement is disruptive. Second, as Pollack et al. (2010) find, wealthier residents moving into TOD neighborhoods actually drive more and use transit less, leading to declines in transit share of commute modes in over half the transit-rich neighborhoods they studied. This means that transit ridership is not supported and climate change improvements are not realized. Third, as lower-income households are displaced, low-earning workers lose connections to jobs, either in the TOD itself or accessed via new transit (Puget Sound Sage, 2012). Yet, when TOD is equitable, it can have very positive impacts, as reported by the Partnership for Sustainable

Communities in Cleveland, where a BRT connects low-income residents with strategic job locations, housing and communities have been stabilized, and affordability is preserved. 
A challenge for considering whether a new BRT system will have substantial neighborhood gentrification effects is that most research on this topic is about fixed rail, and there are fewer BRT systems in the U.S. BRT can be difficult to define because of the wide range of various BRT systems currently in operation (Wright and Hook, 2007, p. 13). However, the minimum requirements for a transit system to be considered a BRT by the Institute for Transportation Development Policy are that it contains each of these five elements: "dedicated right-of-way, busway alignment, off-board fare collection, intersection treatments, and platformlevel boarding” (ITDP, 2016a, p. 26).

BRT systems are becoming increasingly popular as a flexible, low-cost alternative to light rail and other fixed guideway transit systems. The initial BRT investment cost and maintenance cost can be significantly cheaper than light rail, and because BRT vehicles are not attached to a permanent railway they are able to drive away from their normal route to provide additional service. "BRT systems will typically cost 2 to 20 times less than a light rail transit (LRT) system and 10 to 100 times less than a metro system,” (Write and Hook, 2007, p. 11).

Because they are affordable and effective at improving transit speeds, BRT systems have been popular in large, highly congested cities of developing countries. Highly rated, GoldStandard BRT systems have been developed in cities like Curitiba, Rio de Janeiro, and Belo Horizonte, Brazil; Guangzhou, China; Botoga, Columbia; Guadalajara, Mexico; Lima, Peru; and Guatemala City, Guatemala (ITDP, 2016b). There are BRT systems currently operating in over 200 cities worldwide (http://brtdata.org/).

Cities in the United States have also invested in BRT, but at a lower rate. There are BRT systems currently located in 20 U.S. cities (BRTData.org, 2016). The first was launched in 1977, soon after the world's first BRT system in Curitiba, Brazil, in 1974 (Nelson and Ganning, 2015, p. 25). The next BRT systems in the U.S. weren't developed until decades later. The MAX BRT in Las Vegas was launched in 2004 and the Orange Line in Los Angeles in 2005. The Healthline BRT in Cleveland (ITDP, 2016b) and the CTfastrak in Hartford (ITDP, 2016a, p. 23) are the two most highly rated BRT systems in the U.S., receiving the Silver Standard from the Institute for Transportation Development Policy. The United States has yet to build a Gold-Standard BRT.

Several studies from outside the United States indicate that BRT station areas incur land value and rent premiums on residential and commercial properties. In literature reviews by Nelson and Ganning (2015) and Mulley et al. (2016), many instances of land value premiums are found near BRT stations in large cities in the United States, Canada, Columbia, China and South Korea. Slight premiums for property near BRT stations were found in Brisbane, Australia (Mulley et al., 2016, p. 51). In a study of BRT systems in Cleveland, Eugene-Springfield, Kansas City, Las Vegas and Pittsburgh, significant premiums for office rents, on the order of "14 to 31 percent of the mean," were found within a half mile of BRT station areas (Nelson and Ganning, 2015, p. 73).

Recent studies have also found that BRT stations in the U.S. incur premiums on residential and commercial property, with proximity to BRT station areas comparable to premiums incurred by light rail transit (LRT) systems. Tables adapted from the literature reviews 
of Rodriguez and Mojica (2009) and Perk and Catala (2009) are shown in the appendix at the end of this document and show that most LRT station areas incur property value premiums both of these studies indicate BRT station premiums that are comparable to LRT.

In a literature review conducted by Nelson and Ganning (2015), the authors cite Thole and Sumus (2009) who say that “...there are no apparent differences between the land use incentives offered by cities for BRT versus LRT projects” (p. 55). In the same literature review, Nelson and Ganning find that “...BRT can be as influential as rail systems in encouraging urban redevelopment (Cervero, 2013; Cervero and Dai, 2014, p.55).”

Transportation cost savings are thought to drive residential property value increases with proximity to BRT station areas (Nelson and Ganning, 2015, p. 89). Nelson and Ganning reference Higgins and Kanaroglou (2015) in their assertion that transportation cost savings are capitalized into property values near station areas. In an analysis of 12 BRT lines operating in the U.S. in 2010, Nelson and Ganning find that “...household transportation costs as a share of income increases with respect to distance from BRT stations to about eight miles away.” (2015, p. 89)

If BRT lines are to be used as an affordable way to initiate TOD, it is important that they strive toward LRT's speed and ease of access. A dedicated lane is essential to mimicking the high-speed, fixed-guideway features of rail-based systems (Cervero and Dai, 2014). Adding dedicated median-lane bus service to a BRT system in Seoul, South Korea, nearly doubled the operating speed and triggered intensified land uses (high-density, mixed-use development) along the BRT corridor, which land markets capitalized into land price premiums within 300 meters of BRT stops (Cervero and Kang, 2011). In developing countries, BRT has proven successful at enacting dense, mixed-use TOD (Cervero and Dai, 2014).

Of course, there is variation on the property value effects of both BRT and LRT systems. Nelson and Ganning (2015) reference a study by Cervero and Duncan (2002), in which a small negative premium is found for residential property near BRT lines in Los Angeles. In an analysis of the effect of BRT stations on housing prices in Brisbane, Australia, Mulley et al. (2016) find a negative effect of station areas on housing prices closer to the central business district and a positive effect on housing prices in the suburbs (p. 48). According to Mulley et al., the benefits of BRT stations may be offset by congestion and other disamenities of the inner city. Put another way, "it is well established that transit investments, paper maps, and illustrative plans, by themselves, are not capable of spurring TOD (Knight and Trygg, 1977; Cervero et al., 2004)” (Cervero and Dai, 2014, p. 135). 


\subsection{HOUSING ANALYSIS}

\subsection{METHODS}

\subsubsection{Geographic units}

The geographic segments used in the analysis are followed by the report from Metro (Powell-Division Transit and Development Project Opportunities \& Constraints, 2014). While the segments from the report were originally eight segments, this analysis employed an aggregated segment using the original one from the report in order to better align with the Census tract boundaries. While analyzing at the smaller geographic unit is preferred for the housing analysis generally, we had to make three sections of the corridor in order to better utilize the tracts, the smallest geographic unit available for HUD Comprehensive Housing Affordability Strategy (CHAS) data. Those three segments are created by considering the demographic profiles, dwelling unit status, neighborhood characteristics, and original segments by Metro.

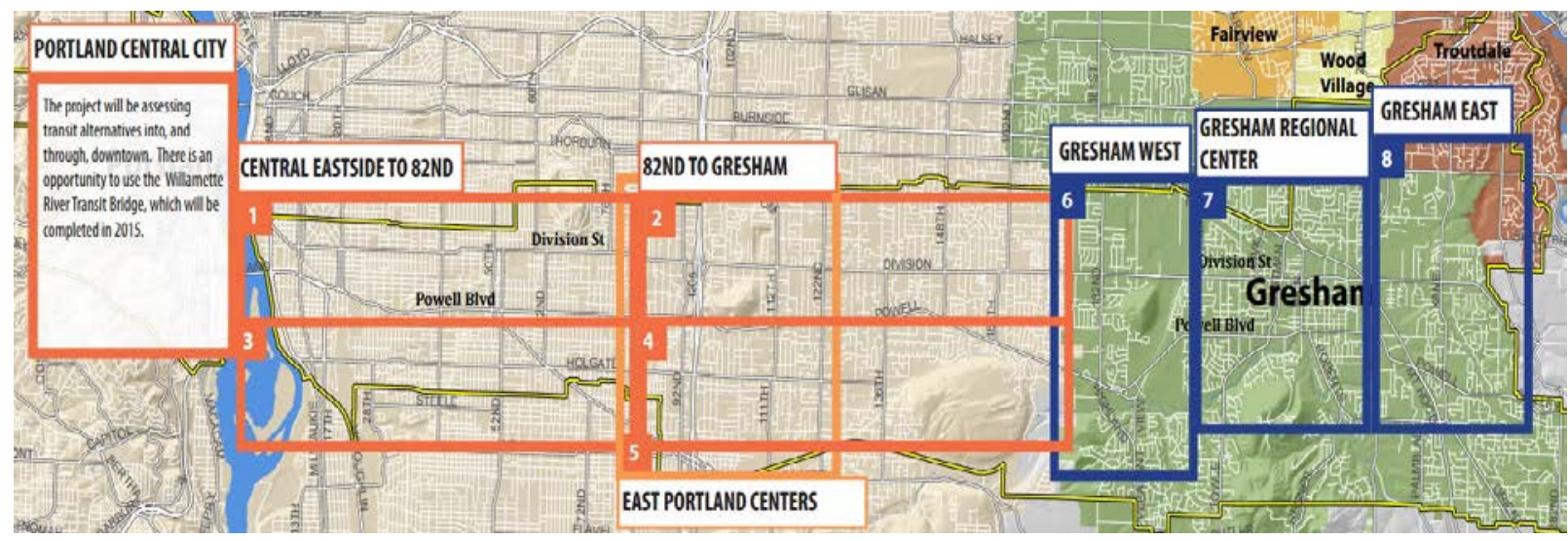

Figure 3.1. Original proposed segments along the corridor by Metro (2014)

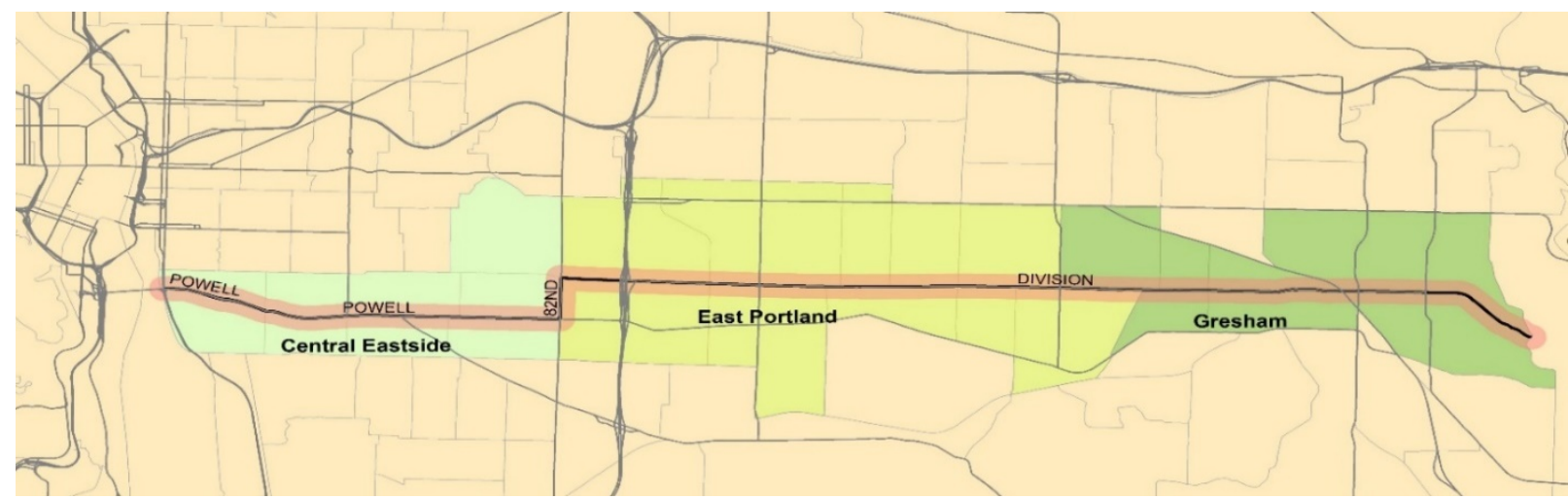

Figure 3.2. Segments along the corridor in the analysis 
- $\quad$ Central Eastside Portland: It covers the central eastside to 82nd Avenue and includes two station opportunity areas, Cesar Chaves/Powell and Foster/Powell.

- $\quad$ East Portland: It starts with the Jade District on 82nd and ends at 182nd Avenue in the beginning of west Gresham. This segment includes the Jade District station opportunity area, Division midway, and 162nd station opportunity area.

- $\quad$ Gresham: The last segment includes 182nd Avenue all the way eastward to the corridor in Gresham.

\subsubsection{Analysis approach}

Housing analysis utilizes the readily available public data sources and real estate data from the private sector. Following the previous study in precarious housing and vulnerability by Pendall et al. (2012) and gentrification and displacement study by Bates (2013), the analysis examines the current demographic and housing status along the Powell-Division BRT corridor. The analysis aims to address the impact of public investment in the adjacent neighborhoods, especially for the population groups that can be the most vulnerable to the negative consequences. The analysis falls into three categories: household vulnerability to housing issues, precarious housing, and neighborhood conditions and change during BRT planning.

The study in housing and neighborhood change requires looking at a finer scale in order to understand the fundamental dynamics of how the concentration of people and housing are all crossed over to make the intended or unintended outcomes by the public investment (Pendall et al., 2012). In this analysis, we apply the definition of vulnerability and precarious housing by Pendall et al. Vulnerability stands for the characteristics of households, while precarious housing means the vulnerable physical structures of the building or the relationship between the dwelling units and residents to investment or upscale neighborhood change. Methodology and data sources for the analysis are explained by each section below.

\subsubsection{Household vulnerability to housing issues}

Generally, populations vulnerable to displacement risks are more likely to be renters, belong to communities of color, lack college degrees, and have lower incomes (Bates, 2013). Pendall et al. (2012) expands and specifies the vulnerability factors into eight illustrative vulnerabilities: age, race, immigration, family structure, military service, poverty, education, and disability. In order to better operationalize the concept of household vulnerability to housing issues, the analysis utilizes the vulnerable factors including education, income, disability, family structures, immigration, and race.

Every variable was drawn from tract-level American Community Survey (ACS) and HUD Comprehensive Housing Affordability Strategy (CHAS) data, then aggregated to the three segments along the corridor designated for the analysis. Large-family household type has been examined in-depth by tenure and income level. Drawn from the 
CHAS data, cost burden was examined by tenure and income level. Low income was defined as the households with incomes at or below $80 \%$ of the HUD-adjusted median family income (MFI), calculated from 2008-2012 CHAS. Moreover, focusing on the racial equity in housing, the analysis particularly looked at the cost burden by race. Using CHAS data, the analysis was performed in order to see whether disproportionate housing cost burden exists for people of color.

Table 3.1. Data source

\begin{tabular}{l|l|l}
\hline \multicolumn{1}{c|}{ Variable } & \multicolumn{1}{c|}{ Source } & \multicolumn{1}{c}{ Note } \\
\hline Educational attainment & 2010-2014 ACS & Percent bachelor's degree or higher \\
\hline Median household income & 2010-2014 ACS & \\
\hline Household with disabilities & $2010-2014$ ACS & $\begin{array}{l}\text { Percent non-institutional population with } \\
\text { disabilities }\end{array}$ \\
\hline Elderly households & $2010-2014$ ACS & $\begin{array}{l}\text { Percent households with 65 years and } \\
\text { over }\end{array}$ \\
\hline Large families & $\begin{array}{l}\text { 2008-2012 } \\
\text { CHAS, Table 7 }\end{array}$ & $\begin{array}{l}\text { Percent households having five or more } \\
\text { people }\end{array}$ \\
\hline $\begin{array}{l}\text { Single-female headed } \\
\text { households }\end{array}$ & 2010-2014 ACS & $\begin{array}{l}\text { Percent single-female headed parent } \\
\text { households }\end{array}$ \\
\hline $\begin{array}{l}\text { Does not speak English very } \\
\text { well }\end{array}$ & 2010-2014 ACS & $\begin{array}{l}\text { Percent population with language spoken } \\
\text { other than English, speaking English less } \\
\text { than very well }\end{array}$ \\
\hline $\begin{array}{l}\text { Cost-burdened households by } \\
\text { tenure and income level }\end{array}$ & $\begin{array}{l}\text { 2008-2012 } \\
\text { CHAS, Table 8 }\end{array}$ & $\begin{array}{l}\text { Percent cost-burdened households by } \\
\text { tenure and income level }\end{array}$ \\
\hline $\begin{array}{l}\text { Cost-burdened households by } \\
\text { race/ethnicity }\end{array}$ & $\begin{array}{l}\text { 2008-2012 } \\
\text { CHAS, Table 9 }\end{array}$ & $\begin{array}{l}\text { Percent of cost-burdened households by } \\
\text { race }\end{array}$ \\
\hline
\end{tabular}

\subsubsection{Precarious housing}

Pendall et al. (2012) identifies types of housing situations as precarious housing, such as overcrowding, high housing cost burdens, rental units, older units, and multifamily units and mobile homes. These precarious housing units are more susceptible to the risk of gentrification and displacement than other dwelling units. Further, those precarious units are more likely to have adverse outcomes by public investment. 
Table 3.2. Precarious housing factors

\begin{tabular}{|c|c|}
\hline & Description \\
\hline $\begin{array}{l}\text { Overcrowded } \\
\text { housing }\end{array}$ & $\begin{array}{l}\text { Detrimental effects for both parents and children } \\
\text { Linked with poor marital relations, health concerns, and low academic } \\
\text { performance of children } \\
\text { Can be related to poor financial situation or cultural orientation due to immigrant } \\
\text { status }\end{array}$ \\
\hline $\begin{array}{l}\text { High housing } \\
\text { cost burden }\end{array}$ & $\begin{array}{l}\text { Higher cost burden, harder to scrape a living } \\
\text { Affordable housing is less than } 30 \% \text { of household income by HUD }\end{array}$ \\
\hline $\begin{array}{l}\text { Renter } \\
\text { occupancy }\end{array}$ & $\begin{array}{l}\text { More rental units have less social capital and higher mobility } \\
\text { High operating costs can cause disinvestment or abandonment } \\
\text { Profit-seeking investors result in rapid upscaling with condominium conversion }\end{array}$ \\
\hline Age of units & High maintenance costs burden low-income families severely \\
\hline $\begin{array}{l}\text { Multifamily } \\
\text { units }\end{array}$ & $\begin{array}{l}\text { Direct consequence of its rental tenure } \\
\text { Structure type and tenure work as vulnerability of dwelling units }\end{array}$ \\
\hline $\begin{array}{l}\text { Mobile } \\
\text { homes }\end{array}$ & $\begin{array}{l}\text { Rapid depreciation } \\
\text { More hostile and predatory environment to mobile home owners }\end{array}$ \\
\hline
\end{tabular}

In addition, housing mismatch is a key factor to understanding inequality of housing demand and supply in the property market. The analysis examines the number of affordable housing units and the housing mismatch along the corridor in order to see whether these units serve the low-income people enough. Low income was defined as the households with incomes at or below $80 \%$ of the HUD-adjusted MFI, calculated from 2008-2012 CHAS. Therefore, affordable housing units were defined as those having rental rates that are affordable to households earning below $80 \%$ of HUD Area Median Family Income. Rents are considered affordable when the household spends $30 \%$ or less of its monthly income on housing; the CHAS dataset assigns units with rents at or below this level with the variable RHUD80. Particularly, affordable housing units and mismatch focused on rental housing units only.

All variables for the precarious housing employed tract-level ACS, CHAS and CoStar. Considering the likelihood of getting converted and involved in displacement, the drilldown analysis of multifamily buildings was performed. Tract-level ACS and CHAS estimates were aggregated and assembled to each designated segment, then compared to the countywide, citywide and corridor-wide estimates. 
Table 3.3. Data sources

\begin{tabular}{l|l|l}
\hline \multicolumn{1}{c|}{ Variable } & \multicolumn{1}{c}{ Source } & \multicolumn{1}{c}{ Note } \\
\hline Renter occupied & $2010-2014$ ACS & Percent renter occupied housing units \\
\hline Single family & $2010-2014$ ACS & Percent single-family detached housing units \\
\hline Multifamily buildings & $2010-2014$ ACS & $\begin{array}{l}\text { Percent multifamily buildings by number of } \\
\text { units, particularly categorized by fewer than } \\
10 \text { units and more than 20 units }\end{array}$ \\
\hline Built before 1970 & $2010-2014$ ACS & Percent housing units built before 1970 \\
\hline Overcrowded & $2010-2014$ ACS & $\begin{array}{l}\text { Percent housing units having occupants more } \\
\text { than one per room }\end{array}$ \\
\hline Affordable housing stock & $\begin{array}{l}2008-2012 \text { CHAS, } \\
\text { Table 15C }\end{array}$ & $\begin{array}{l}\text { Number and percent of renter-occupied } \\
\text { housing units by RHUD. }\end{array}$ \\
\hline Housing mismatch & $\begin{array}{l}2008-2012 \text { CHAS, } \\
\text { Table 15C }\end{array}$ & $\begin{array}{l}\text { Percent rental housing units at an income } \\
\text { level occupied by higher-income households. }\end{array}$ \\
\hline Conversion and sale & CoStar & $\begin{array}{l}\text { Multifamily property sales during } 2011 \text { and } \\
2016\end{array}$ \\
\hline
\end{tabular}

\subsubsection{Neighborhood conditions and change during BRT planning}

Using ArcGIS and publicly available data and housing market data from the Regional Multiple Listing Service (RMLS), gentrification typology was created to look at the neighborhood's change during the two time periods, 2000-2010 and 2010-2015, respectively. The first version of the typology simply follows and updates the previous gentrification study by Bates (2013). We also overlay the typology based on publicly released data (Census and ACS) used in housing market condition indicators with data from private-sector entities such as Zillow and RMLS. Housing data have long been an issue since the housing market changes too fast to capture fully its characteristics at the finer level in the public data. Therefore, the latter typology uses the same data for vulnerable population and demographic change indicators, but different housing market data in order to see whether the difference in the data causes the different results in typology. 
Table 3.4. Typology methodology and data sources

\begin{tabular}{|c|c|c|}
\hline & Methods & Data Sources \\
\hline $\begin{array}{l}\text { Vulnerable } \\
\text { population }\end{array}$ & $\begin{array}{l}\text { Vulnerability in year } 2 \text { (at least } 3 \text { out of } 4 \text { ) } \\
\text { - \% low-income households }>\text { Portland city } \\
\text { • \% college educated }<\text { Portland city } \\
\text { • \% renters }>\text { Portland city } \\
\text { - \% nonwhite }>\text { Portland city }\end{array}$ & $\begin{array}{l}2000 \text { Decennial Census } \\
\text { 2006-2010 ACS } \\
\text { 2010-2014 ACS } \\
\text { 2005-2009 CHAS } \\
\text { 2009-2013 CHAS } \\
\end{array}$ \\
\hline $\begin{array}{l}\text { Demographic } \\
\text { change }\end{array}$ & $\begin{array}{l}\text { Demographic Change between year } 1 \text { and year } 2 \\
\text { Either: at least } 3 \text { out of the following } 4 \text {, } \\
\text { • \% change in share of renters } \\
\text { - \% change in college educated } \\
\text { • \% change in nonwhite } \\
\text { - \% change in median household income } \\
\text { Or experienced only } 2 \text { out of } 4 \text {, } \\
\text { - \% change in college educated } \\
\text { - \% change in nonwhite }\end{array}$ & $\begin{array}{l}2000 \text { Decennial Census } \\
\text { 2006-2010 ACS } \\
\text { 2010-2014 ACS }\end{array}$ \\
\hline $\begin{array}{l}\text { Housing } \\
\text { market } \\
\text { condition }\end{array}$ & $\begin{array}{l}\text { Housing Market Condition } \\
\text { - Median home value in year } 2 \\
\text { - Home value appreciation rates between year } 1 \text { and } 2 \text {, } \\
\text { the previous time period of year } 1 \text { and } 2\end{array}$ & $\begin{array}{l}2000 \text { Decennial Census } \\
\text { 2006-2010 ACS } \\
\text { 2010-2014 ACS } \\
\text { 2000-10-15 RMLS, median } \\
\text { home sales prices } \\
\text { 2010-2015 Zillow Rent Index }\end{array}$ \\
\hline
\end{tabular}

Source: Bates (2013) 


\subsection{RESULTS: HOUSING ALONG THE POWELL-DIVISION CORRIDOR IS INSUFFICIENT AND AT RISK}

Planners are concerned with how new transit infrastructure may affect low-income households and families nearby. That issue suggests a need for predicting changes to the housing market and mitigating against rent increases that could displace people. However, housing needs along the Powell-Division corridor are substantial, even before construction of new transit infrastructure.

Powell-Division households are likely to be transit-dependent (at least somewhat), and are already significantly pressured by housing prices. The corridor is perhaps 18,000 rental units short of adequate affordable housing stock. We are able to segment by income groups to see that households making 30-50\% of area Median Family Income are the most housing cost-burdened, and rental units affordable to that income range are likely to be leased by higher-income households. (This is further illustrated by the relatively lower rates of cost-burden for households earning $50-80 \%$ of area median income).

At the same time, the rental housing stock along the corridor is "precarious" - a term used to mean at risk of conversion, demolition, or serious deterioration. Many housing units are already in poor condition. Over the past five years, there have been 50 buildings (with over 1,300 units) sold. These buildings were overwhelmingly "2-star” rated (just above obsolete) and had moderate and low rents.

While many of the neighborhoods that will be connected by this new BRT are identified as having the potential to gentrify, the amount of housing need that exists today is far greater than likely changes due to neighborhood investment that comes along with transit service.

\subsubsection{Household vulnerability to housing issues}

Our analysis of vulnerable households focuses on the types of people who are protected under Title VI of the Civil Rights Act, and some additional characteristics that we know are related to housing challenges. There are certain demographic groups that face barriers in the housing market and need to be specially considered in planning for transit due to historic factors of limitations on mobility and access to transportation resources. In terms of housing access and vulnerability to displacement if prices/rents increase, we look at households that are already costburdened as those most likely to be affected by change.

Vulnerable households are clustered past east 82nd Avenue. The close-in section of the transit corridor does not look markedly different from the rest of Portland, but the East Portland and Gresham sections have more vulnerable populations than Portland-Multnomah County as a whole. 
Table 3.5. Vulnerability indicators

\begin{tabular}{l|c|c|c|c|c|c}
\hline & Multnomah & Portland & Corridor & $\begin{array}{c}\text { Central } \\
\text { Eastside }\end{array}$ & $\begin{array}{c}\text { East } \\
\text { Portland }\end{array}$ & Gresham \\
\hline $\begin{array}{l}\text { Educational } \\
\text { attainment }\end{array}$ & $40.3 \%$ & $44.4 \%$ & $24.3 \%$ & $45.5 \%$ & $15.7 \%$ & $17.8 \%$ \\
\hline Median income & $\$ 52,845$ & $\$ 53,230$ & $\$ 43,574$ & $\$ 54,190$ & $\$ 38,083$ & $\$ 42,423$ \\
\hline $\begin{array}{l}\text { People with } \\
\text { disabilities }\end{array}$ & $12.6 \%$ & $12.1 \%$ & $14.6 \%$ & $11.5 \%$ & $15.8 \%$ & $15.0 \%$ \\
\hline Elderly & $20.3 \%$ & $19.5 \%$ & $22.6 \%$ & $17.7 \%$ & $24.8 \%$ & $24.3 \%$ \\
\hline $\begin{array}{l}\text { Single female- } \\
\text { headed }\end{array}$ & $10.8 \%$ & $9.9 \%$ & $15.1 \%$ & $9.7 \%$ & $17.5 \%$ & $16.7 \%$ \\
\hline households & $9.3 \%$ & $8.9 \%$ & $16.4 \%$ & $7.2 \%$ & $23.3 \%$ & $10.5 \%$ \\
\hline $\begin{array}{l}\text { Does not speak } \\
\text { English well }\end{array}$ & 308,595 & 252,185 & 58,450 & 16,875 & 28,663 & 12,912 \\
\hline Total HH & & & & & & \\
\hline
\end{tabular}

Data Source: ACS 2010-2014, 2008-2012 CHAS

Compared to Multnomah County, where $40 \%$ of adults over 25 years old have a BA, only $24 \%$ of Powell-Division corridor adults have a college degree. This figure is much lower in East Portland-Gresham, at around 16\%. (Close-in households on the transit line are as educated as the overall figure for the county.)

Median household income for the corridor is $82 \%$ of the countywide and citywide median household income. Although west of 82nd has a slightly higher median income than the county's and city's, East Portland has very low median household income at almost $72 \%$. The median income of the Gresham area in the corridor has about $80 \%$ of the median household income.

There are slightly higher percentages of people with disabilities in the corridor, particularly past east 82nd Avenue, where the rate is three to four percentage points higher than the overall population.

Looking at the population that is 65 years and older, and 75 years and older, there are slightly more elderly people living along the corridor in East Portland-Gresham. The elderly population in the close-in Powell-Division corridor is equal or even lower than the city/county average. Nearly one-quarter of households living past east 82nd have someone over 65 years old (county average is 20\%); and 6.5\% have someone over 75 years old (compared to 4.8\%).

The proportion of single-female parent households on the corridor is substantially greater than the overall. In the city of Portland overall, just under $10 \%$ of households are headed by a 
single female parent. In East Portland centers, $17.5 \%$ of households are headed by a single female parent.

Multnomah County has 10.8\% single-female parent households; the Gresham area of the corridor has $16.7 \%$ of households headed by a single female parent.

Overall, about 9\% of Portland/Multnomah County residents speak another language than English at home and don't speak English well. These are people with limited English proficiency who are protected by Title VI. In the transit corridor, that figure is $16.4 \%$. In East Portland centers, it is even higher at $23 \%$.

Large families can struggle to find adequate housing without being overcrowded. This is particularly true for low-income renters, as rental housing is usually smaller than owneroccupied housing. For renters, there are larger families among low-income households than there are among low-income households generally in Portland - nearly double the proportion. Among large families, extremely low incomes are much higher at $12 \%$ of large families having incomes below $30 \%$ of area median income (compared to just $6 \%$ overall). There are also many large families with incomes between $50-80 \%$ of area median. These large families and low-income, large families live east of 82nd Avenue.

Table 3.6. Renter: Large family by income level

\begin{tabular}{l|c|c|c|c|c|c}
\hline & Multnomah & Portland & Corridor & $\begin{array}{c}\text { Central } \\
\text { Eastside }\end{array}$ & $\begin{array}{c}\text { East } \\
\text { Portland }\end{array}$ & $\begin{array}{c}\text { Gresham } \\
\text { West }\end{array}$ \\
\hline $\mathrm{AMI}<30$ & $\begin{array}{c}2,314 \\
(6.3 \%)\end{array}$ & $\begin{array}{c}1,724 \\
(5.5 \%)\end{array}$ & $\begin{array}{c}1,185 \\
(11.6 \%)\end{array}$ & $\begin{array}{c}110 \\
(4.1 \%)\end{array}$ & $\begin{array}{c}805 \\
(15.4 \%)\end{array}$ & $\begin{array}{c}270 \\
(11.6 \%)\end{array}$ \\
\hline $30 \leq \mathrm{AMI}<50$ & $\begin{array}{c}1,656 \\
(6.5 \%)\end{array}$ & $\begin{array}{c}1,051 \\
(5.2 \%)\end{array}$ & $\begin{array}{c}424 \\
(6.0 \%)\end{array}$ & $\begin{array}{c}15 \\
(1.0 \%)\end{array}$ & $\begin{array}{c}179 \\
(5.9 \%)\end{array}$ & $\begin{array}{c}230 \\
(9.2 \%)\end{array}$ \\
\hline $50 \leq \mathrm{AMI}<80$ & $\begin{array}{c}1,722 \\
(5.9 \%)\end{array}$ & $\begin{array}{c}1,148 \\
(4.9 \%)\end{array}$ & $\begin{array}{c}710 \\
(9.1 \%)\end{array}$ & $\begin{array}{c}25 \\
(1.2 \%)\end{array}$ & $\begin{array}{c}405 \\
(12.3 \%)\end{array}$ & $\begin{array}{c}280 \\
(11.9 \%)\end{array}$ \\
\hline $80 \leq \mathrm{AMI}<10$ & $\begin{array}{c}679 \\
(4.9 \%)\end{array}$ & $\begin{array}{c}480 \\
(4.3 \%)\end{array}$ & $\begin{array}{c}243 \\
(6.5 \%)\end{array}$ & $\begin{array}{c}24 \\
(1.9 \%)\end{array}$ & $\begin{array}{c}175 \\
(12.3 \%)\end{array}$ & $\begin{array}{c}44 \\
(4.1 \%)\end{array}$ \\
\hline $100 \leq \mathrm{AMI}$ & $\begin{array}{c}893 \\
(2.8 \%)\end{array}$ & $\begin{array}{c}610 \\
(2.2 \%)\end{array}$ & $\begin{array}{c}248 \\
(4.2 \%)\end{array}$ & $\begin{array}{c}0 \\
(0.0 \%)\end{array}$ & $\begin{array}{c}145 \\
(6.7 \%)\end{array}$ & $\begin{array}{c}103 \\
(5.9 \%)\end{array}$ \\
\hline Total HH & 137,441 & 114,250 & 34,755 & 9,650 & 15,135 & 9,970 \\
\hline
\end{tabular}

Source: 2008-2012 CHAS

Note: Each cell presents the number of large family households corresponding to income range with the percentage of large family households. Total households mean total number of households in each geographic unit. 


\subsubsection{Housing cost burden}

Households that are already cost-burdened - that is, paying more than $30 \%$ of their monthly income on housing - are more likely to be displaced by rising housing costs with redevelopment on the corridor.

Table 3.7. Cost-burdened households by tenure

\begin{tabular}{l|c|c|c|c|c|c}
\hline & Multnomah & Portland & Corridor & $\begin{array}{c}\text { Central } \\
\text { Eastside }\end{array}$ & $\begin{array}{c}\text { East } \\
\text { Portland }\end{array}$ & $\begin{array}{c}\text { Gresham } \\
\text { West }\end{array}$ \\
\hline All & $\begin{array}{c}123,122 \\
(40.5 \%)\end{array}$ & $\begin{array}{c}100,529 \\
(40.6 \%)\end{array}$ & $\begin{array}{c}30,441 \\
(44.3 \%)\end{array}$ & $\begin{array}{c}7,615 \\
(40.4 \%)\end{array}$ & $\begin{array}{c}14,195 \\
(47.9 \%)\end{array}$ & $\begin{array}{c}8,631 \\
(42.6 \%)\end{array}$ \\
\hline Owner & $\begin{array}{c}55,055 \\
(33.1 \%)\end{array}$ & $\begin{array}{c}44,376 \\
(33.3 \%)\end{array}$ & $\begin{array}{c}11,989 \\
(35.2 \%)\end{array}$ & $\begin{array}{c}2,895 \\
(31.4 \%)\end{array}$ & $\begin{array}{c}5,762 \\
(39.8 \%)\end{array}$ & $\begin{array}{c}3,332 \\
(32.4 \%)\end{array}$ \\
\hline Renter & $\begin{array}{c}68,067 \\
(49.5 \%)\end{array}$ & $\begin{array}{c}56,153 \\
(49.2 \%)\end{array}$ & $\begin{array}{c}18,452 \\
(53.1 \%)\end{array}$ & $\begin{array}{c}4,720 \\
(48.9 \%)\end{array}$ & $\begin{array}{c}8,433 \\
(55.7 \%)\end{array}$ & $\begin{array}{c}5,299 \\
(53.2 \%)\end{array}$ \\
\hline
\end{tabular}

Source: 2008-2012 CHAS

Note: Each cell includes the number of households that are cost-burdened with the percent of cost-burdened households by each geographic unit.

Generally, renters have a higher cost burden than homeowners. Cost burdens are greater than citywide figures for renters along Powell-Division, although the proportion of costburdened renters declines with moves eastward along the corridor. Regardless of tenure status, households living in East Portland have the highest cost burden compared to those in the overall city and the county. (See Appendix A, Table A.3 and A.4 for additional details on cost burden, tenure and income.)

Table 3.8. Cost-burdened households with low income ( $<80 \%$ AMFI)

\begin{tabular}{l|c|c|c|c|c|c}
\hline & Multnomah & Portland & Corridor & $\begin{array}{c}\text { Central } \\
\text { Eastside }\end{array}$ & $\begin{array}{c}\text { East } \\
\text { Portland }\end{array}$ & $\begin{array}{c}\text { Gresham } \\
\text { West }\end{array}$ \\
\hline All & $\begin{array}{c}94,134 \\
(68.9 \%)\end{array}$ & $\begin{array}{c}76,992 \\
(69.3 \%)\end{array}$ & $\begin{array}{c}25,044 \\
(68.7 \%)\end{array}$ & $\begin{array}{c}6,120 \\
(69.4 \%)\end{array}$ & $\begin{array}{c}12,006 \\
(68.5 \%)\end{array}$ & $\begin{array}{c}6,918 \\
(68.5 \%)\end{array}$ \\
\hline Owner & $\begin{array}{c}30,283 \\
(67.5 \%)\end{array}$ & $\begin{array}{c}24,447 \\
(68.3 \%)\end{array}$ & $\begin{array}{c}7,540 \\
(66.4 \%)\end{array}$ & $\begin{array}{c}1,695 \\
(68.9 \%)\end{array}$ & $\begin{array}{c}3,937 \\
(65.9 \%)\end{array}$ & $\begin{array}{c}1,908 \\
(65.2 \%)\end{array}$ \\
\hline Renter & $\begin{array}{c}63,851 \\
(69.6 \%)\end{array}$ & $\begin{array}{c}52,545 \\
(69.8 \%)\end{array}$ & $\begin{array}{c}17,504 \\
(69.8 \%)\end{array}$ & $\begin{array}{c}4,425 \\
(69.6 \%)\end{array}$ & $\begin{array}{c}8,069 \\
(69.8 \%)\end{array}$ & $\begin{array}{c}5,010 \\
(69.8 \%)\end{array}$ \\
\hline
\end{tabular}

Source: 2008-2012 CHAS

Note: number and percent of cost-burdened households by tenure and geographic unit. 
The cost burden of the low-income households (below $80 \%$ area median family income (AMFI)) is much higher than that of all income levels. Regardless of tenure status, the households living in the corridor are likely to remain cost-burdened; $69.8 \%$ of low-income renters are cost-burdened in the corridor. Interestingly, low-income households residing west of 82nd along the corridor appear to have more severe cost burden compared to the eastern portion of the corridor, unlike the results from those with all income levels.

Out of 63,851 cost-burdened renters in the county, $27 \%$ are concentrated in the corridor.

For renters, extremely low-income households are far more cost-burdened than they are in the city as a whole. For those earning under $30 \%$ area median income (AMI), the cost-burden rate is 10 percentage points higher than the average, with the largest gaps in Gresham. For other income levels, there is less cost-burden incidence as you move east along the corridor. For renters earning $50-80 \%$ of AMI, they are less cost-burdened than renters citywide at that income level.

\subsubsection{Racial equity impacts}

Looking at renter households by race at different locations provides information about racial equity impacts of potential gentrification. Black renters have very high cost burdens, more so than elsewhere in the city; the gap between cost burden in Gresham and the citywide average is 18 percentage points.

Asian renter households have far greater cost burdens in the Jade District than they do citywide (by 20 percentage points). Latino households who rent are most burdened in East Portland (eight percentage points higher than the average for Latino cost burden). 
Table 3.9. Cost-burdened households by race/ethnicity

\begin{tabular}{|c|c|c|c|c|c|c|}
\hline & Multnomah & Portland & Corridor & $\begin{array}{c}\text { Central } \\
\text { Eastside }\end{array}$ & East Portland & Gresham \\
\hline White & $\begin{array}{c}47,259 \\
(47.3 \%)\end{array}$ & $\begin{array}{c}38,763 \\
(46.5 \%)\end{array}$ & $\begin{array}{c}12,260 \\
(50.7 \%)\end{array}$ & $\begin{array}{c}3,670 \\
(48.0 \%)\end{array}$ & $\begin{array}{c}4,650 \\
(49.5 \%)\end{array}$ & $\begin{array}{c}3,940 \\
(55.0 \%)\end{array}$ \\
\hline Black & $\begin{array}{c}6,598 \\
(61.0 \%)\end{array}$ & $\begin{array}{c}6,000 \\
(61.0 \%)\end{array}$ & $\begin{array}{c}1,354 \\
(67.0 \%)\end{array}$ & $\begin{array}{c}220 \\
(55.0 \%)\end{array}$ & $\begin{array}{c}965 \\
(68.7 \%)\end{array}$ & $\begin{array}{c}169 \\
(78.6 \%)\end{array}$ \\
\hline Asian & $\begin{array}{c}2,979 \\
(48.4 \%)\end{array}$ & $\begin{array}{c}2,641 \\
(48.4 \%)\end{array}$ & $\begin{array}{c}1,294 \\
(59.8 \%)\end{array}$ & $\begin{array}{c}299 \\
(52.9 \%)\end{array}$ & $\begin{array}{c}880 \\
(64.7 \%)\end{array}$ & $\begin{array}{c}115 \\
(47.9 \%)\end{array}$ \\
\hline $\begin{array}{l}\text { Native } \\
\text { American }\end{array}$ & $\begin{array}{c}758 \\
(58.2 \%)\end{array}$ & $\begin{array}{c}558 \\
(56.2 \%)\end{array}$ & $\begin{array}{c}280 \\
(64.5 \%)\end{array}$ & $\begin{array}{c}95 \\
(54.3 \%)\end{array}$ & $\begin{array}{c}115 \\
(79.9 \%)\end{array}$ & $\begin{array}{c}70 \\
(60.9 \%)\end{array}$ \\
\hline $\begin{array}{l}\text { Pacific } \\
\text { Islander }\end{array}$ & $\begin{array}{c}573 \\
(70.0 \%)\end{array}$ & $\begin{array}{c}423 \\
(77.2 \%)\end{array}$ & $\begin{array}{c}159 \\
(58.0 \%)\end{array}$ & $\begin{array}{c}4 \\
(100.0 \%)\end{array}$ & $\begin{array}{c}85 \\
(58.6 \%)\end{array}$ & $\begin{array}{c}70 \\
(56.0 \%)\end{array}$ \\
\hline Hispanic & $\begin{array}{c}7,819 \\
(55.4 \%)\end{array}$ & $\begin{array}{c}5,949 \\
(58.0 \%)\end{array}$ & $\begin{array}{c}2,659 \\
(56.8 \%)\end{array}$ & $\begin{array}{c}319 \\
(50.3 \%)\end{array}$ & $\begin{array}{c}1500 \\
(66.7 \%)\end{array}$ & $\begin{array}{c}840 \\
(46.7 \%)\end{array}$ \\
\hline Others & $\begin{array}{c}2,071 \\
(46.9 \%)\end{array}$ & $\begin{array}{c}1,815 \\
(47.0 \%)\end{array}$ & $\begin{array}{c}407 \\
(42.7 \%)\end{array}$ & $\begin{array}{c}125 \\
(53.2 \%)\end{array}$ & $\begin{array}{c}189 \\
(46.1 \%)\end{array}$ & $\begin{array}{c}93 \\
(30.1 \%)\end{array}$ \\
\hline Total HH & 137,441 & 114,250 & 34,755 & 9,650 & 15,135 & 9,970 \\
\hline
\end{tabular}

Source: 2008-2012 CHAS

Note: number and percent of cost-burdened households by race and geographic unit. 


\subsubsection{Precarious housing}

Precarious housing units are those more likely to be converted by tenure, lost from the stock due to quality declines, or to undergo major renovation or demolition in order to build more expensive housing.

Table 3.10. Precarious housing indicators

\begin{tabular}{l|c|c|c|c|c|c}
\hline & Multnomah & Portland & Corridor & $\begin{array}{c}\text { Central } \\
\text { Eastside }\end{array}$ & $\begin{array}{c}\text { East } \\
\text { Portland }\end{array}$ & Gresham \\
\hline Renter occupied & $46.3 \%$ & $47.2 \%$ & $52.7 \%$ & $51.4 \%$ & $51.5 \%$ & $57.0 \%$ \\
\hline Single family & $56.1 \%$ & $56.1 \%$ & $53.2 \%$ & $59.0 \%$ & $55.2 \%$ & $40.9 \%$ \\
\hline $\begin{array}{l}\text { Multifamily } \\
\text { buildings, fewer } \\
\text { than 10 units }\end{array}$ & $15.8 \%$ & $15.3 \%$ & $21.6 \%$ & $22.9 \%$ & $18.7 \%$ & $26.6 \%$ \\
\hline $\begin{array}{l}\text { Multifamily } \\
\text { buildings, more } \\
\text { than 20 units }\end{array}$ & $16.3 \%$ & $18.0 \%$ & $11.3 \%$ & $7.8 \%$ & $12.1 \%$ & $14.1 \%$ \\
\hline $\begin{array}{l}\text { Built before } \\
\text { 1970 }\end{array}$ & $55.1 \%$ & $62.1 \%$ & $48.6 \%$ & $71.8 \%$ & $47.7 \%$ & $20.5 \%$ \\
\hline $\begin{array}{l}\text { Overcrowded } \\
\text { (occupants per } \\
\text { room >1) }\end{array}$ & $3.2 \%$ & $3.0 \%$ & $5.7 \%$ & $1.9 \%$ & $8.1 \%$ & $5.3 \%$ \\
\hline \begin{tabular}{l} 
Total HH \\
\hline
\end{tabular} & 326,952 & 267,514 & 61,789 & 17,643 & 30,595 & 13,551 \\
\hline
\end{tabular}

Data Source: ACS 2010-2014

About half of the housing units are rented along the corridor. The corridor as a whole, and each section of it, has more renters than the county and city average. Gresham has the highest percentage of rentals, with $57 \%$ of units.

The corridor's housing is 58\% single-family detached housing. Compared to the overall housing stock in the county, there are more smaller sized, multifamily housing units in the corridor -multifamily buildings with fewer than 10 units. In the inner portion of the corridor (west of 82nd Avenue), there are more duplex and three- and four-unit buildings than average. This can be related to the fact that most of the dwelling units were built before 1970 instead of big multifamily buildings in the inner section of the corridor. In East Portland, three- and fourunit buildings are dominant. Moreover, it has the highest percentage of large multifamily buildings (50 or more units) along the corridor. In Gresham the five- to nine-unit building is 
more common. Together with the duplex and three- and four-unit buildings in the section, half of the multifamily buildings are made up of small, multifamily housing units in Gresham.

Based on the conditions field study conducted by BPS, these small multifamily buildings may be in poor condition. In the station-area target zones, surveyors found 483 units in duplex, triplex, quad buildings and manufactured housing that are in poor condition. In the 162nd and Division area, $43 \%$ of all units were rated poor; in Division midway it was $29 \%$. These units are older and may not be capitalized sufficiently to provide repairs without displacing tenants.

\subsubsection{Housing mismatch and unit availability}

There are already substantial shortages of housing for low-income people along the corridor, even though affordable units in the corridor account for $28 \%$ of low-cost units in the county.

This supply shortage is exacerbated when households live in units that are priced for lower-income households' affordability. At least one-third of units at each affordability level are occupied by households of higher incomes. That mismatch squeezes households who can just afford those units. Units at 50-80\% AMI are dominant among all affordable units. However, $34 \%$ of those affordable in the corridor are taken by higher-income households. This crowding out of lower-income households is most prevalent in units that are affordable to households making $30-50 \%$ of the AMFI. Over half of the units affordable to these very low-income households are inhabited by households with higher incomes. Extremely low-income affordable units (under 30\% AMI) are least likely to have higher-income residents - which is likely due to higher-income residents looking for better condition/amenities.

Table 3.11. Affordable housing stock

\begin{tabular}{l|c|c|c|c|c|c}
\hline & Multnomah & Portland & Corridor & $\begin{array}{c}\text { Central } \\
\text { Eastside }\end{array}$ & $\begin{array}{c}\text { East } \\
\text { Portland }\end{array}$ & Gresham \\
\hline $\begin{array}{l}\text { Number of } \\
\text { affordable } \\
\text { housing units }\end{array}$ & 107,606 & 87,219 & 29,869 & 8,145 & 13,045 & 8,679 \\
\hline RHUD $<30$ & $11.8 \%$ & $12.6 \%$ & $11.1 \%$ & $11.4 \%$ & $12.7 \%$ & $8.6 \%$ \\
\hline $30 \leq$ RHUD $<50$ & $22.7 \%$ & $22.8 \%$ & $24.0 \%$ & $22.1 \%$ & $27.8 \%$ & $20.3 \%$ \\
\hline $50 \leq$ RHUD $<80$ & $65.4 \%$ & $64.7 \%$ & $64.8 \%$ & $66.5 \%$ & $59.6 \%$ & $71.1 \%$ \\
\hline
\end{tabular}

Source: 2008-2012 CHAS

Note: Affordable rental housing units are regarded as those having rental rates below $80 \%$ of HUD Area Median Family Income. RHUD 30; The gross rent for this unit is affordable to a household making 30\% of HAMFI. RHUD50; The gross rent for this unit is not affordable to a household making 30\% of HAMFI, but is affordable to a household making 50\% of HAMFI. RHUD80; The gross rent for this unit is not affordable to a household making $50 \%$ of HAMFI, but is affordable to a household making $80 \%$ of HAMFI. 
Table 3.12. Housing mismatch

\begin{tabular}{|c|c|c|c|c|c|c|}
\hline & Multnomah & Portland & Corridor & $\begin{array}{c}\text { Central } \\
\text { Eastside }\end{array}$ & $\begin{array}{c}\text { East } \\
\text { Portland }\end{array}$ & Gresham \\
\hline RHUD $<30$ & $\begin{array}{c}4,565 \\
(35.8 \%)\end{array}$ & $\begin{array}{c}3,629 \\
(33.1 \%)\end{array}$ & $\begin{array}{c}1,145 \\
(34.4 \%)\end{array}$ & $\begin{array}{c}228 \\
(24.5 \%)\end{array}$ & $\begin{array}{c}598 \\
(36.1 \%)\end{array}$ & $\begin{array}{c}319 \\
(42.9 \%)\end{array}$ \\
\hline $30 \leq$ RHUD $<50$ & $\begin{array}{c}10,178 \\
(41.6 \%)\end{array}$ & $\begin{array}{c}8,236 \\
(41.4 \%)\end{array}$ & $\begin{array}{c}3,223 \\
(44.9 \%)\end{array}$ & $\begin{array}{c}975 \\
(54.2 \%)\end{array}$ & $\begin{array}{c}1,473 \\
(40.7 \%)\end{array}$ & $\begin{array}{c}775 \\
(44.0 \%)\end{array}$ \\
\hline $50 \leq$ RHUD $<80$ & $\begin{array}{c}23,249 \\
(33.0 \%)\end{array}$ & $\begin{array}{c}19,231 \\
(34.1 \%)\end{array}$ & $\begin{array}{c}5,790 \\
(29.9 \%)\end{array}$ & $\begin{array}{c}2,070 \\
(38.2 \%)\end{array}$ & $\begin{array}{c}1,965 \\
(25.3 \%)\end{array}$ & $\begin{array}{c}1,755 \\
(28.4 \%)\end{array}$ \\
\hline $80 \leq$ RHUD & $\begin{array}{c}12,833 \\
(50.7 \%)\end{array}$ & $\begin{array}{c}11,945 \\
(51.6 \%)\end{array}$ & $\begin{array}{c}1,248 \\
(32.6 \%)\end{array}$ & $\begin{array}{c}490 \\
(38.6 \%)\end{array}$ & $\begin{array}{c}433 \\
(25.8 \%)\end{array}$ & $\begin{array}{c}325 \\
(36.9 \%)\end{array}$ \\
\hline $\begin{array}{l}\text { Total rental } \\
\text { housing units }\end{array}$ & 137,441 & 114,250 & 34,755 & 9,650 & 15,135 & 9,970 \\
\hline
\end{tabular}

Source: 2008-2012 CHAS

Note: Number and Percentage of affordable units at an income level occupied by higher-income households 


\subsubsection{Conversion and sale}

According to analysis of CoStar data on multifamily property sales, over the past five years there have been 50 buildings (with over 1,300 units) sold. These buildings were overwhelmingly "2-star" rated (just above obsolete) and had moderate and low rents. Most were small buildings (under 10 units).

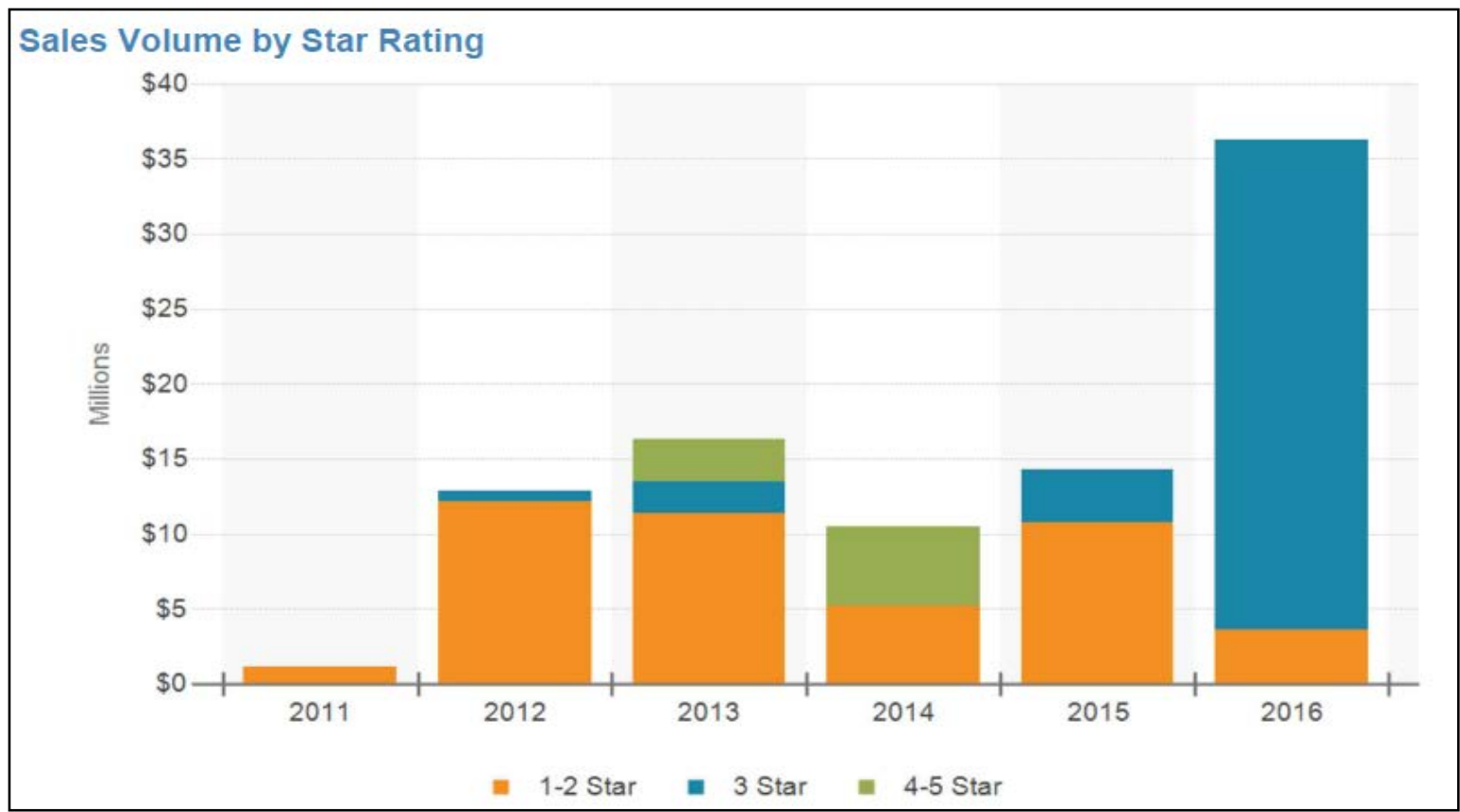

Figure 3.3. Multifamily buildings sold 2011-2016 in corridor 


\subsection{CONCLUSIONS: NEIGHBORHOOD CONDITIONS AND CHANGE DURING BRT PLANNING}

What baseline information about neighborhood conditions and early change during a planning stage of a BRT are important for planners to recognize to consider programming to avoid housing displacement? We started with an analysis of overall neighborhood conditions combining the analysis of how vulnerable populations, demographic change, and housing market change overlap. Some neighborhoods are already experiencing some gentrification pressures, while others have the potential to do so because of their combinations of vulnerable groups with housing that could be redeveloped. Below we show the stages of neighborhoods in 2010, based on the 2000-2010 period, and updated housing market data showing changes from 2010-2015.

Our analysis shows a few susceptible tracts appeared in the western boundary of East Portland during the early time period of the typology; tracts in East and upper north Portland were defined as susceptible to gentrification in the latter time period, 2010-2015. Nearly half of the tracts in East Portland were categorized in the early stage of gentrification or susceptible in 2015. They have many vulnerable households and consistent price increases. These results reveal that gentrification pressure moves towards East Portland compared to the results during 2000 and 2010. However, overall, many neighborhoods on this line are not gentrifying, but are persistently low income.

Rent increases are highest in the closer-in neighborhoods along the BRT. While the increases are not large in the eastern half, compared to some neighborhoods in Portland, they are high in absolute terms - from 20-40\% increases in rent. Given the high rent burdens of many residents, these increases of up to $30 \%$ will be too much to bear. For sales prices, there are several neighborhoods with high price increases, over $60 \%$ in five years. In both tenures, the neighborhoods that were identified as areas with gentrification occurring in 2010 are experiencing continued high price increases, and some new areas that were not identified as susceptible to gentrification are also experiencing high price increases near the BRT line. 


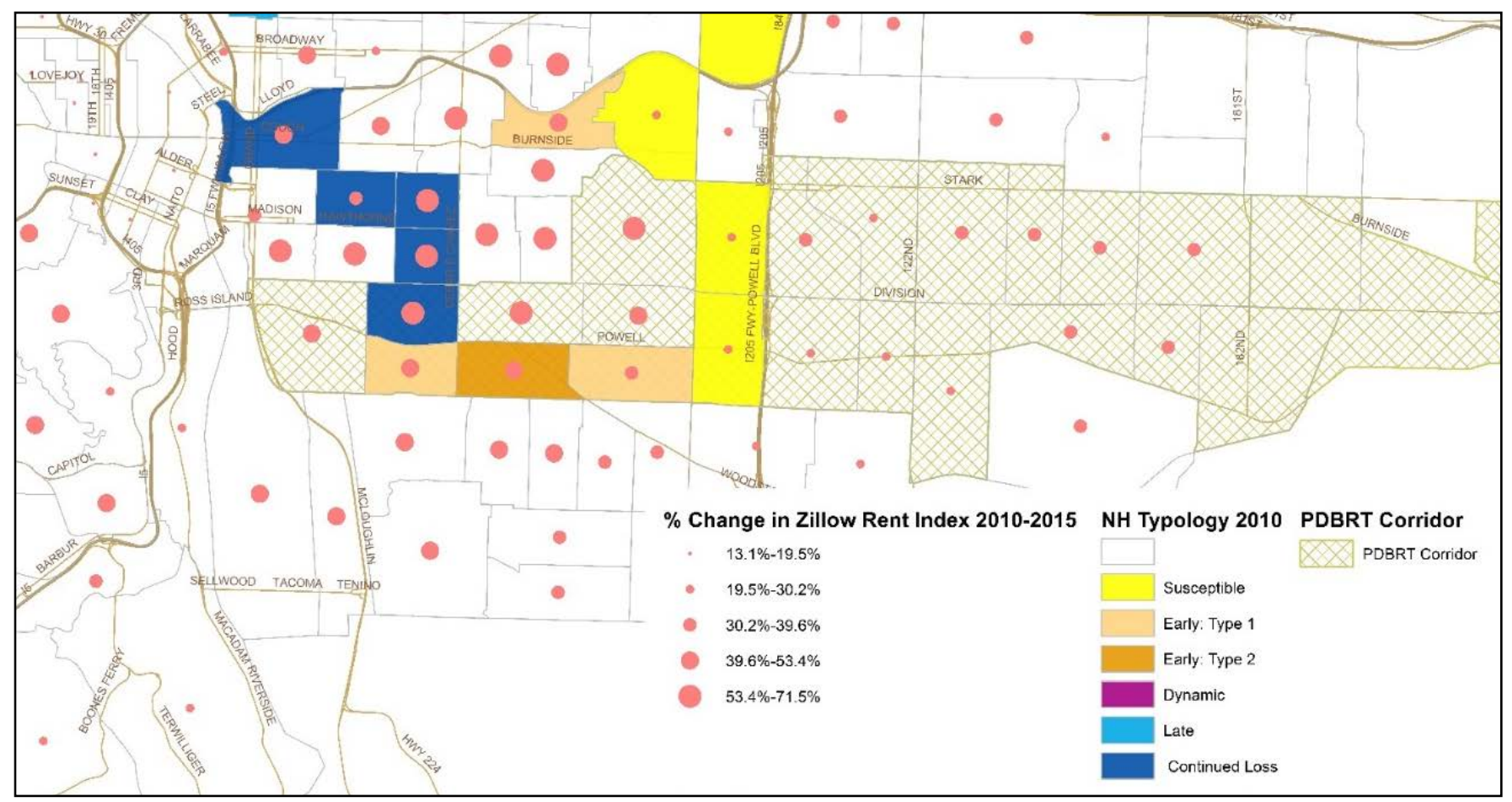

Figure 3.4. 2010 gentrification stage with rent index increases from 2010-2015

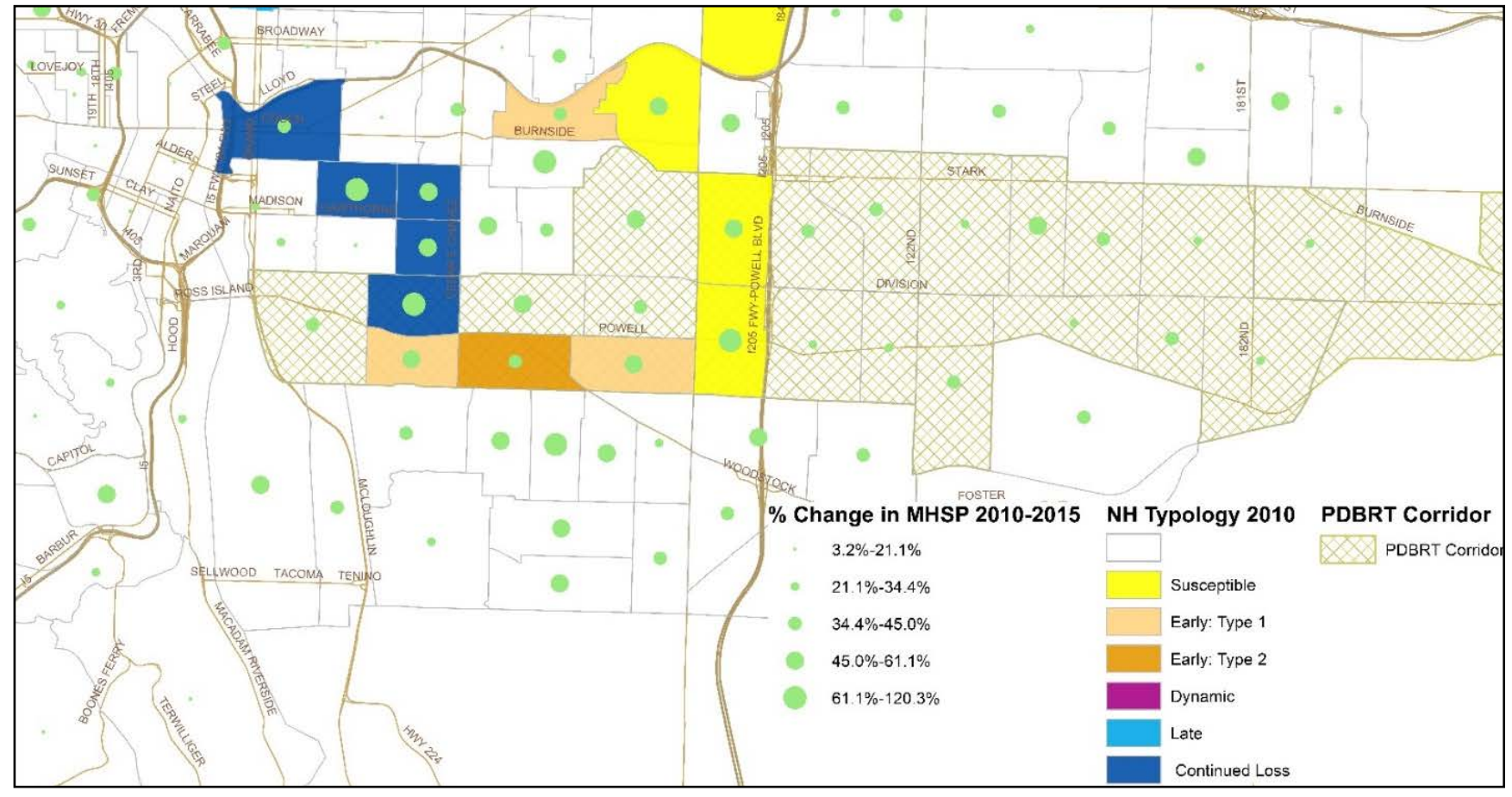

Figure 3.5. 2010 gentrification stage with sales price index increases from 2010-2015 
Will the BRT create more gentrification? The Powell-Division corridor has several types of neighborhoods along it. Some of those are already high income, with no real change to lowincome displacement despite high housing price increases. Many are currently what we call "persistently low income" and are areas that are actually receiving low-income in-migration as people are displaced from close-in neighborhoods. If households move eastwards along the corridor, the overall line population proportions of each household type may not change so much as to have a major impact on overall demographics along the line. In other words, the same mix of people will live on the BRT line, just with low-income households living further east than they do now. What is the most important factor in predicting future neighborhood change? The overall trend of the neighborhood towards either gentrification or receiving displaced people and becoming more poor. The current conditions and trend in the neighborhood are larger magnitude of impact than adding the BRT to existing bus lines. That does not mean planners should not be concerned about housing displacement in this area, as gentrification pressures are moving eastward (on and off transit lines). 


\subsection{TRANSPORTATION ANALYSIS}

To understand how the Powell-Division bus rapid transit (BRT) proposal will serve different populations, we need to compare their trip-making needs with the proposed investments. Public transit systems consist of fixed networks - how well they serve different populations' trips depends on where those trips start and stop. Most public transit networks are designed for specific trip types. For example, traditional radial transit networks inherited from early streetcar networks were designed to serve radial suburb-to-central-city trips. Examples of these would be TriMet lines 4, 8, 9, 14 and 15. As land-use patterns in metropolitan areas diversified and scattered, additional circumferential services have been added over the years. Good examples are the 75 and 72 lines.

In this section we will analyze the correspondence of the BRT proposal with the tripmaking patterns of certain populations in the corridor. We will rely on visual analysis of the home and work locations of different workers as well as a breakdown of the Census data on public transit use in different areas of the corridor. This will help to identify how well the investment will serve existing populations, where there are significant differences between travel needs and the investment, and which job centers will become more accessible with the investment.

Research questions:

- What is the current journey-to-work for residents along the corridor? Where do residents work and how do they commute?

- Will current job locations be linked more effectively by the new BRT? What additional transit services could improve access more?

- What new potential job locations are made more accessible via BRT? How does the new east-west bus rapid transit increase accessibility of jobs for low-income residents? 


\subsection{VEHICLE OWNERSHIP RATES}

Vehicle ownership in the corridor would indicate the importance of public transit investments and how that importance may differ over the length of the corridor. Data from the American Community Survey, however, show that car ownership along the corridor does not vary substantially (though is very low compared to national averages). Table 17 shows the overall average number of vehicles per household, and Figure 1 in Appendix 2 shows the breakdown in the share of households in each section of the corridor with different numbers of vehicles. Households of concern with no vehicles vary only slightly and peak in the Central Eastside and East Portland sections of the corridor. The Gresham section has the lowest share of households with no vehicles.

Table 4.1. Average number of vehicles per household

\begin{tabular}{c|c}
\hline Multnomah Co. & 1.47 \\
\hline Portland & 1.42 \\
\hline Corridor & 1.46 \\
\hline Central Eastside & 1.40 \\
\hline East Portland & 1.46 \\
\hline Gresham & 1.51 \\
\hline
\end{tabular}

Source: Estimated by author based on data from ACS 2010-2014

Car ownership seems to be lowest in the Central Eastside and then rises slightly as one proceeds east along the corridor to Gresham, where it is the highest. But the variation of about $10 \%$ from lowest to highest is not great enough to warrant a particular focus on one part of the corridor over another because of low vehicle ownership.

\subsection{TRAVEL MODE CHOICE IN THE CORRIDOR}

The American Community Survey includes questions about typical travel mode choice to work. Results from the most recent survey are shown in Table 18. Public transit use for commuting is higher in the corridor than in the surrounding geographies, and is highest in the Central Eastside section of the corridor and declines from there going east. Still, among the 
lowest-income workers in the corridor public transit use may be much higher. As all workers are grouped in this data, that difference is not revealed here.

Table 4.2. Mode choice to work (\%)

\begin{tabular}{l|c|c|c|c|c|c|c|c}
\hline & $\begin{array}{c}\text { Drive } \\
\text { alone }\end{array}$ & $\begin{array}{c}\text { Carpoole } \\
\mathbf{d}\end{array}$ & $\begin{array}{c}\text { Public } \\
\text { transit }\end{array}$ & Bike & Walked & Others & $\begin{array}{c}\text { Work at } \\
\text { home }\end{array}$ & $\begin{array}{c}\text { Total } \\
\text { workers }\end{array}$ \\
\hline Multnomah & 60.5 & 9.8 & 10.9 & 5.3 & 5.2 & 1.2 & 7.2 & 375,393 \\
\hline Portland & 58.0 & 9.5 & 11.8 & 6.3 & 5.7 & 1.2 & 7.6 & 308,013 \\
\hline Corridor & 62.4 & 11.7 & 12.2 & 3.5 & 3.7 & 1.0 & 5.4 & 70,136 \\
\hline $\begin{array}{l}\text { Central } \\
\text { Eastside }\end{array}$ & 57.8 & 8.2 & 14.2 & 8.9 & 3.7 & 0.9 & 6.3 & 21,893 \\
\hline $\begin{array}{l}\text { East } \\
\text { Portland }\end{array}$ & 63.0 & 14.3 & 12.0 & 1.1 & 3.1 & 1.1 & 5.4 & 33,269 \\
\hline Gresham & 68.0 & 11.1 & 9.7 & 1.0 & 5.0 & 1.1 & 4.1 & 14,974 \\
\hline
\end{tabular}

Source: ACS $2010-2014$

Note: Total workers are workers 16 years and over,

\subsection{JOB LOCATIONS AND TRIP PATTERNS OF CORRIDOR WORKERS AND RESIDENTS}

A visual analysis of the corridor can allow us to understand how well this project proposal will serve existing travel needs, and connect workers to jobs and other destinations. Since this study was designed to foreground potential equity issues with the BRT proposal, we will compare middle- and high-income job locations and worker travel patterns with those of low-income workers. While there are private data sets available to map jobs of different types, we relied on a publicly available data set through the Census Bureau, called the Longitudinal Household-Employment Dynamics data set. The data set assembles survey data about workers' home and work locations and allows one to estimate where workers from one location commute, or in the reverse, where workers in one location live. This data set is accessible through an online tool called OnTheMap. In the data set, workers are broken into low-, medium- and high-wage groups; the low wage is $\$ 1,250$ per month or less (roughly the poverty line for a single worker), while the high-wage group, at more than \$3,333 per month, represents about the top 50\% of all workers. Throughout the analysis presented, we compare the lowest-income workers $(<\$ 1,250 / \mathrm{mo})$ to this top 50\% worker group ( $>\$ 3,333 / \mathrm{mo})$, with the higher-income group maps on top. 


\subsection{JOB LOCATIONS IN THE REGION}

Using the OnTheMap tool, we mapped the location of low-income jobs and higherincome jobs, shown in Appendix B, Figure B.2. While the high-income jobs are concentrated at the central Portland end of the corridor, low-income jobs are more dispersed along the corridor and also away from the corridor - north near the airport and south near Clackamas Town Center. Considering the connections to perpendicular, north-south bus routes, the BRT proposal appears to support travel close to job locations for both high-income and low-income workers. Lowincome workers appear more likely to need to transfer away from the corridor than high-income workers.

\subsection{JOB LOCATIONS FOR THOSE LIVING ALONG THE CORRIDOR}

Using the OnTheMap tool, we mapped the job location of low-income and higher-income workers who live along the corridor. We made these maps for workers' home locations along the corridor, in four sections: Central Eastside (to SE 82nd Avenue), East Portland (to 148th Avenue), west Gresham (to 212th Avenue) and central Gresham (up to Stark and Cleveland). A visual analysis of each segment reveals significant differences in the distribution of work locations for workers living along the corridor. These maps are shown in Figures B.2 through B.6 in Appendix B. We summarize some of the major patterns and differences in Table 4.3.

Table 4.3. Areas of job locations

\begin{tabular}{|c|c|c|c|}
\hline $\begin{array}{c}\text { Segment (Home } \\
\text { locations) }\end{array}$ & Low income & High income & Notable differences \\
\hline Central Eastside & $\begin{array}{l}\text { Downtown Portland and } \\
\text { Central Eastside }\end{array}$ & $\begin{array}{l}\text { Downtown Portland and } \\
\text { OHSU area }\end{array}$ & $\begin{array}{l}\text { Low-income jobs more } \\
\text { dispersed on eastside and } \\
\text { southeast }\end{array}$ \\
\hline East Portland & $\begin{array}{l}\text { Downtown Portland, } \\
\text { inner Northeast, Jade } \\
\text { District, Mall 205, East } \\
\text { Portland and Gresham, } \\
\text { Clackamas Town Center }\end{array}$ & $\begin{array}{l}\text { Downtown Portland and } \\
\text { small amounts at } \\
\text { Clackamas Town Center } \\
\text { and Boeing (Northeast) }\end{array}$ & $\begin{array}{l}\text { Low-income jobs more } \\
\text { widely dispersed } \\
\text { throughout eastern areas } \\
\text { and Gresham }\end{array}$ \\
\hline Gresham West & $\begin{array}{l}\text { Downtown Portland, } \\
\text { inner Northeast, Mall 205, } \\
\text { central and northeast } \\
\text { Gresham, Clackamas } \\
\text { Town Center, small } \\
\text { amounts at the airport }\end{array}$ & $\begin{array}{l}\text { Downtown Portland, } \\
\text { inner Northeast, Boeing, } \\
\text { and small amounts at } \\
\text { Clackamas Town Center }\end{array}$ & $\begin{array}{l}\text { Low-income jobs more } \\
\text { widely dispersed } \\
\text { throughout East Portland } \\
\text { and Gresham }\end{array}$ \\
\hline Gresham Central & $\begin{array}{l}\text { Downtown Portland, } \\
\text { inner Northeast, } \\
\text { Clackamas Town Center } \\
\text { and central and east } \\
\text { Gresham }\end{array}$ & $\begin{array}{l}\text { Downtown Portland, } \\
\text { OHSU, inner Northeast, } \\
\text { Boeing and central } \\
\text { Gresham }\end{array}$ & $\begin{array}{l}\text { Low-income jobs in } \\
\text { higher concentrations at } \\
\text { Clackamas Town Center } \\
\text { and in Gresham }\end{array}$ \\
\hline
\end{tabular}


Across the four segments, corridor residents seem to work most heavily in downtown Portland and inner Northeast. Low-income residents have much more widely dispersed work locations in general, with greater representation at Clackamas Town Center and in Gresham and East Portland. High-income workers have greater representation at OHSU and Boeing. Without estimating numbers of workers, it appears that a greater share of high-income workers will have a one-seat ride on the proposed BRT between home locations along the corridor and work locations in downtown Portland. They may need to transfer to access jobs at OHSU, inner Northeast or Boeing. Low-income workers will be less directly served by the BRT and will more likely need to transfer to reach their final work destination. It is hard to estimate the exact shares of workers needing to transfer based on the maps, but it is clear that low-income workers will have a higher likelihood of needing to transfer.

\subsection{HOME LOCATIONS FOR THOSE WORKING ALONG THE CORRIDOR}

Similar to the previous visual analysis of work locations, the census tool allows us to map the home locations of those who work along the corridor. We performed a similar visual analysis of the same four segments of the corridor. These maps are shown in Figures 7-10 in Appendix 2. General impressions from the maps are found here in Table 4.4.

Table 4.4. Areas of home locations

\begin{tabular}{l|l|l|l}
\hline Segment (Job locations) & \multicolumn{1}{c|}{ Low income } & \multicolumn{1}{c}{ High income } & \multicolumn{1}{c}{ Notable differences } \\
\hline Central Eastside & $\begin{array}{l}\text { Southeast and Northeast } \\
\text { Portland }\end{array}$ & $\begin{array}{l}\text { Inner Southeast and } \\
\text { Northeast Portland } \\
\text { extending far east and } \\
\text { south to Clackamas } \\
\text { County }\end{array}$ & $\begin{array}{l}\text { High-income home } \\
\text { locations more dispersed }\end{array}$ \\
\hline East Portland & $\begin{array}{l}\text { Concentrated very near } \\
\text { this segment of the } \\
\text { corridor }\end{array}$ & $\begin{array}{l}\text { All over East Portland, } \\
\text { Gresham, Clackamas } \\
\text { County and Happy Valley }\end{array}$ & $\begin{array}{l}\text { High-income home } \\
\text { locations more dispersed }\end{array}$ \\
\hline Gresham West & $\begin{array}{l}\text { East Portland, and } \\
\text { Southwest and Southeast } \\
\text { Gresham }\end{array}$ & $\begin{array}{l}\text { Mostly central, southwest } \\
\text { and southeast Gresham }\end{array}$ & $\begin{array}{l}\text { High-income home } \\
\text { locations slightly more } \\
\text { dispersed }\end{array}$ \\
\hline Gresham Central & $\begin{array}{l}\text { Southwest and Southeast } \\
\text { Gresham }\end{array}$ & Central and east Gresham & $\begin{array}{l}\text { High-income home } \\
\text { locations seem more } \\
\text { dispersed and more east } \\
\text { and northeast }\end{array}$ \\
\hline
\end{tabular}

The visual analysis of home locations for people working along the corridor results in different conclusions compared to the analysis of work locations. In general, high-income people 
who work along the corridor live in more dispersed areas, especially more east and south into Clackamas County. In this light, the BRT would directly serve those who live outside the corridor but work along the BRT. More of these workers would need to transfer to the BRT to access jobs along the corridor. Furthermore, a higher share of higher-income workers would need to transfer than low-income workers to access jobs along the corridor.

\subsection{CONCLUSIONS}

The analysis presented here reveals several patterns, which can highlight the relative utility of the proposed BRT for commuting in the corridor. The analysis of vehicle ownership and transit ridership did not reveal any significant deviations in transit use or transit dependency along the corridor. Vehicle ownership was similar along the segments of the corridor; transit use was highest in the inner Southeast and declined as one travels out to Gresham. This is not cause for alarm that a particular part of the corridor was more in need of transit than any other. While transit use is highest in the inner Southeast, outer sections of the corridor contain higher shares of lower-income workers and thus will also have a high need for transit service. The analysis of job and home locations reveals that the BRT proposal will well serve low-income residents who currently work along the corridor and who appear to also live close to the corridor. Higherincome residents who live along the corridor will also be well served by the proposal as they will probably require, on average, fewer transfers to reach their final work destinations. This opposite finding for the job and work analysis shows that the transit investment doesn't necessarily serve one group better than the other, but that both groups will benefit from investments in perpendicular services that distribute trips into East Portland, Gresham and inner Northeast Portland. For the most part, these services already exist but additional services may be needed in the far East Portland and west Gresham areas.

Returning to our original research questions, here are some basic findings:

- What is the current journey-to-work for residents along the corridor? Where do residents work and how do they commute?

Using Census data, we mapped in Figures 2 through 10 the locations of employees' residences and work locations for those who live or work along the corridor.

- Will current job locations be linked more effectively by the new BRT? What additional transit services could improve access more?

Both low-income and high-income workers will benefit from the investment, though both will need additional perpendicular services to connect to homes and jobs. Low-income workers especially need connections to Mall 205, Clackamas Town Center and south and southeast Gresham. High-income workers especially need connections to OHSU, inner Northeast Portland, Happy Valley and Clackamas County, Boeing, and southeast and northeast Gresham. 
- What new potential job locations are made more accessible via BRT? How does the new east-west BRT increase accessibility of jobs for low-income residents?

The proposal does not increase job access to areas not already served by transit, but by providing faster service it may reduce commute travel times for current users and attract new riders to the service. Both high-income and low-income residents benefit from the investment in terms of job access. 


\subsection{DISCUSSION AND CONCLUSION}

In linking transit planning and housing, planners have been focused on new neighborhood development and displacement from the transit project. However, the alreadyexisting housing needs are important to first consider as a priority. In the Powell-Division corridor, we are concerned with low-income neighborhoods potentially gentrifying, but we first note there are serious issues with a lack of affordable housing. These needs are particularly intense in populations of protected classes in terms of environmental justice and fair housing aspects of civil rights law - communities of color and immigrant/families with limited English proficiency, people with disabilities, and extremely low-income households. It is possible that some of those problems will get worse with a new transit line, but the trends in the housing market show that those problems are already worsening without any new public investment. Given the magnitude of existing housing problems, the notion of building an elaborate model to predict new housing instability may not be worth the effort.

However, that should not mean that planners take no responsibility for housing displacement in the area. An overall equity lens on planning and cumulative impacts of market dynamics suggests not trying to precisely measure the harms from a single project and then mitigate only those. Rather, taking the bigger picture of equity in planning for transportation and housing suggests using a new bus service plan as an opportunity to open a discussion about neighborhoods and their needs. The example from Lexington, KY, was a clear precedent in this direction. The planning of a new transit corridor is an opportunity to consider neighborhoods beyond the service line. We demonstrate here a drilldown on household vulnerability, housing precarity, and the mismatch of housing needs and housing availability. Using such an analysis, planners can prioritize types of households or housing units to address. Knowing that it is important for low-income households to be near transit should suffice to prioritize affordable housing as part of TOD planning. As planners consider the cumulative effects of neighborhood housing market changes citywide along with the opportunities for careful planning afforded by a process to build out transit infrastructure, these questions of housing and community access to opportunity can become a focus.

Our conclusion here is that, on balance, the project has positive potential for benefiting low-income residents and workers in the corridor. The problem of housing vulnerability and lack of access to opportunity cannot be blamed on this project, but we ask how this project can alleviate housing vulnerability and lack of access. Paying close attention to existing affordable housing and the additional commuting needs of low-income workers in the corridor will leverage the project for positive benefits. For instance, looking more closely at north-south bus service will help to bring low-income workers living along the corridor an opportunity they currently access away from the corridor - especially north and south in East Portland. The project is also beneficial because we know that East Portland is an increasingly important location for lowincome households and transit service will allow them to possibly forgo vehicle ownership or reduce their vehicle holdings, which can alleviate household budgets. That benefit, along with affirmative attention to preserving existing affordable housing, will create a win-win for lowincome households. Still, we show that the lowest-income households in this corridor will be under pressure to move out. The question remains for the cities in this region: How to address this alarming issue? 


\subsection{REFERENCES}

Bates, Lisa K. 2013. Gentrification and Displacement Study: Implementing an Equitable, Inclusive Development Strategies in the Context of Gentrification. Report prepared for the City of Portland Bureau of Planning and Sustainability. Retrieved (4/14/15) from:

https://www.portlandoregon.gov/bps/article/454027

BRTData.org (2016). BRT Data for the US.

http://brtdata.org/location/northern_america/united_states

Chapple, Karen. 2009. Mapping Susceptibility to Gentrification: The Early Warning Toolkit. Report of the Center for Community Innovation, Univ of California - Berkeley.

Cervero, R. B. (2013). Linking urban transport and land use in developing countries. Journal of Transport and Land Use, 6(1), 7-24.

Cervero, R., \& Dai, D. (2014). BRT TOD: Leveraging transit oriented development with bus rapid transit investments. Transport Policy, 36, 127-138.

http://doi.org/10.1016/j.tranpol.2014.08.001

Cervero, R., \& Duncan, M. (2002). Land value impacts of rail transit services in Los Angeles County. Report Prepared for National Association of Realtors Urban Land Institute. Retrieved from https://drcog.org/documents/TODvalueLosangeles.pdf

Dawkins, C., \& Moeckel, R. (2016). Transit-Induced Gentrification: Who Will Stay, and Who Will Go?. Housing Policy Debate, 1-18. Gresham.

ECONorthwest. 2015. Gresham Neighborhood Change Analysis. Report to the City of

Environmental Protection Agency (EPA) (2016) EPA’s Title VI - Policies, Guidance, Settlements, Laws And Regulations. https://www.epa.gov/ocr/epas-title-vi-policies-guidancesettlements-laws-and-regulations\#\#t6policy

Federal Highway Administration (FHWA) (2016). Preserving community cohesion through Southend Park neighborhood redevelopment. Environmental Justice Case studies. https://www.fhwa.dot.gov/environment/environmental_justice/resources/case_studies/case08.cf $\mathrm{m}$

Gauthier, Aimee.2014. "Housing, Transport, and the Fight for Equitable Cities.” Sustainable Transport Winter 2014, no. 25

Golub, A., Guhathakurta, S., \& Sollapuram, B. (2012). Spatial and temporal capitalization effects of light rail in phoenix from conception, planning, and construction to operation. Journal of Planning Education and Research, 32(4), 415-429. 
Higgins, C. D., \& Kanaroglou, P. S. (2015). 40 Years of Modelling Rail Transit's Land Value Uplift in North America: Diverse Methods, Differentiated Outcomes, Debatable Assumptions, and Future Directions. In Transportation Research Board 94th Annual Meeting (No. 15-4103).

Hook, Walter, Stephanie Lotshaw, and Annie Weinstock. 2013. More Development for your Transit Dollar: An Analysis of 21 North American Transit Corridors. Report for the Institute for Transportation and Development Policy. Retrieved (4/14/15) from:

https://www.itdp.org/wp-content/uploads/2013/11/More-Development-For-Your-TransitDollar_ITDP.pdf

ITDP. (2016a). The BRT Standard. Institute for Transportation and Development Policy, New York. https://www.itdp.org/library/standards-and-guides/the-bus-rapid-transit-standard/

ITDP (2016b). BRT Standard Scores. Institute for Transportation and Development Policy, New York. https://www.itdp.org/wp-content/uploads/2014/11/BRT-2014Scorecards2.xlsx

Metro (2014), Powell-Division Transit and Development Project Opportunities \& Constraints. Retrieved from: http://www.oregonmetro.gov/sites/default/files/Planning\%20and\%20Development\%20\%20Corridor\%20Plan s\%20-\%20All\%20Other\%20Records\%20-\%20Powell-Division\%20\%200pportunities\%20and\%20constraints\%20\%28DRAFT\%29.PDF

Moore, Eli, Samir Gambhir, and Phuong Tseng. Belonging and Community Health in Richmond: An Analysis of Changing Demographics and Housing. Report of the Haas Institute for a Fair and Inclusive Society. Univ of California-Berkeley.

Mulley, C., Ma, L., Clifton, G., Yen, B., \& Burke, M. (2016). Residential property value impacts of proximity to transport infrastructure: An investigation of bus rapid transit and heavy rail networks in Brisbane, Australia. Journal of Transport Geography, 54, 41-52.

http://doi.org/10.1016/j.jtrangeo.2016.05.010

Nelson, A. C., \& Ganning, J. (2015). NATIONAL STUDY OF BRT DEVELOPMENT OUTCOMES. University of Utah: National Institute for Transportation and Communities (NITC). http://t4america.org/wp-content/uploads/2016/01/NATIONAL-STUDY-OF-BRTDEVELOPMENT-OUTCOMES-11-30-15.pdf

Partnership for Sustainable Communities. 2012. Transit as Transformation: the Euclid Corridor in Cleveland. Retrieved (4/14/15) from: http://ntl.bts.gov/lib/45000/45700/45740/Cleveland-euclid-corridor.pdf

Perk, V. A., \& Catalá, M. (2009). Land Use Impacts of Bus Rapid Transit: Effects of BRT Station Proximity on Property Values along the Pittsburgh Martin Luther King, Jr. East Busway. Retrieved from https://trid.trb.org/view.aspx?id=1401767 
Pollack, Stephanie, Barry Bluestone, and Chase Billingham. 2010. Maintaining Diversity in America's Transit-Rich Neighborhoods: Tools for Equitable Neighborhood Change. Report of the Dukakis Center for Urban and Regional Policy, Northeastern University.

Puget Sound Sage. 2012. Transit-Oriented Development that’s Healthy, Green and Just. Report.

Rodríguez, D. A., \& Mojica, C. H. (2009). Capitalization of BRT network expansions effects into prices of non-expansion areas. Transportation Research Part A: Policy and Practice, 43(5), 560-571. http://doi.org/10.1016/j.tra.2009.02.003

Rolf Pendall, Brett Theodos \& Kaitlin Franks (2012). Vulnerable people, precarious housing, and regional resilience: an exploratory analysis, Housing Policy Debate, 22:2, 271-296.

Thole, C., \& Samus, J. (2009). Bus Rapid Transit and Development: Policies and Practices that affect Development around Transit (No. FTA-FL-26-7109.2009. 5).

Wright, L., \& Hook, W. (2007). Bus rapid transit planning guide. Institute for Transportation and Development Policy, New York. 



\section{APPENDIX A: ADDITIONAL HOUSING DATA}

Table A.1. Large family by tenure

\begin{tabular}{c|c|c|c|c|c|c}
\hline Multnomah & Portland & Corridor & $\begin{array}{c}\text { Central } \\
\text { Eastside }\end{array}$ & $\begin{array}{c}\text { East } \\
\text { Portland }\end{array}$ & Gresham \\
\hline Owner & $\begin{array}{c}10,989 \\
(6.6 \%)\end{array}$ & $\begin{array}{c}7,710 \\
(5.8 \%)\end{array}$ & $\begin{array}{c}2,981 \\
(8.8 \%)\end{array}$ & $\begin{array}{c}294 \\
(3.2 \%)\end{array}$ & $\begin{array}{c}1,533 \\
(10.6 \%)\end{array}$ & $\begin{array}{c}1,154 \\
(11.2 \%)\end{array}$ \\
\hline \multirow{2}{*}{ Renter } & 7,264 & $\begin{array}{c}5,013 \\
(4.4 \%)\end{array}$ & $\begin{array}{c}2,810 \\
(8.1 \%)\end{array}$ & $\begin{array}{c}174 \\
(1.8 \%)\end{array}$ & $\begin{array}{c}1,709 \\
(11.3 \%)\end{array}$ & $\begin{array}{c}927 \\
(9.3 \%)\end{array}$ \\
\hline
\end{tabular}

Source: 2008-2012 CHAS

Note: Number and percent of large family households by tenure

Regardless of the tenure status, the corridor has more large families compared to the citywide and countywide average. As the corridor goes east, the ratio of large families is higher. East Portland and Gresham have more than double the number of large families than the citywide average. Interestingly, East Portland has a high percentage of large-family renters. It can be related to the fact that the neighborhood around the Jade District has a high number of Asian families who are recent immigrants, and they tend to live as a big family considering their culture and financial instabilities.

Table A.2. Owner: Large family by income level

\begin{tabular}{|c|c|c|c|c|c|c|}
\hline & Multnomah & Portland & Corridor & $\begin{array}{l}\text { Central } \\
\text { Eastside }\end{array}$ & $\begin{array}{c}\text { East } \\
\text { Portland }\end{array}$ & $\begin{array}{c}\text { Gresham } \\
\text { West }\end{array}$ \\
\hline $\mathrm{AMI}<30$ & $\begin{array}{c}536 \\
(5.6 \%)\end{array}$ & $\begin{array}{c}376 \\
(4.7 \%)\end{array}$ & $\begin{array}{c}104 \\
(4.4 \%)\end{array}$ & $\begin{array}{c}19 \\
(3.0 \%)\end{array}$ & $\begin{array}{c}45 \\
(3.6 \%)\end{array}$ & $\begin{array}{c}40 \\
(8.6 \%)\end{array}$ \\
\hline $30 \leq \mathrm{AMI}<50$ & $\begin{array}{c}1,080 \\
(8.9 \%)\end{array}$ & $\begin{array}{c}801 \\
(8.4 \%)\end{array}$ & $\begin{array}{c}395 \\
(11.7 \%)\end{array}$ & $\begin{array}{c}25 \\
(3.7 \%)\end{array}$ & $\begin{array}{c}240 \\
(13.0 \%)\end{array}$ & $\begin{array}{c}130 \\
(15.2 \%)\end{array}$ \\
\hline $50 \leq \mathrm{AMI}<80$ & $\begin{array}{c}1,994 \\
(8.6 \%)\end{array}$ & $\begin{array}{c}1,346 \\
(7.4 \%)\end{array}$ & $\begin{array}{c}658 \\
(11.7 \%)\end{array}$ & $\begin{array}{c}55 \\
(4.8 \%)\end{array}$ & $\begin{array}{c}359 \\
(12.5 \%)\end{array}$ & $\begin{array}{c}244 \\
(15.2 \%)\end{array}$ \\
\hline $\begin{array}{l}80 \leq \mathrm{AMI}<10 \\
0\end{array}$ & $\begin{array}{c}1,358 \\
(8.0 \%)\end{array}$ & $\begin{array}{c}915 \\
(7.0 \%)\end{array}$ & $\begin{array}{c}434 \\
(10.0 \%)\end{array}$ & $\begin{array}{c}55 \\
(6.0 \%)\end{array}$ & $\begin{array}{c}234 \\
(10.9 \%)\end{array}$ & $\begin{array}{c}145 \\
(11.6 \%)\end{array}$ \\
\hline $100 \leq \mathrm{AMI}$ & $\begin{array}{c}6,021 \\
(5.8 \%)\end{array}$ & $\begin{array}{c}4,272 \\
(5.1 \%)\end{array}$ & $\begin{array}{c}1,390 \\
(7.6 \%)\end{array}$ & $\begin{array}{c}140 \\
(2.4 \%)\end{array}$ & $\begin{array}{c}655 \\
(10.3 \%)\end{array}$ & $\begin{array}{c}595 \\
(9.7 \%)\end{array}$ \\
\hline
\end{tabular}

Source: 2008-2012 CHAS

Note: Number and percent of large family households at an income level 
There are more low-income (income ranging from 30\% to $80 \%$ of the Median Family Income, adjusted for size) homeowners who are large families in the corridor, particularly East Portland and Gresham, than there are in the city/county overall, by about four percentage points.

Table A.3. Cost-burdened owner households breakdown

\begin{tabular}{l|c|c|c|c|c|c}
\hline & Multnomah & Portland & Corridor & $\begin{array}{c}\text { Central } \\
\text { Eastside }\end{array}$ & $\begin{array}{c}\text { East } \\
\text { Portland }\end{array}$ & Gresham \\
\hline $\mathrm{AMI}<30$ & $\begin{array}{c}8,006 \\
(83.1 \%)\end{array}$ & $\begin{array}{c}6,648 \\
(83.4 \%)\end{array}$ & $\begin{array}{c}1,903 \\
(81.2 \%)\end{array}$ & $\begin{array}{c}570 \\
(89.1 \%)\end{array}$ & $\begin{array}{c}968 \\
(78.1 \%)\end{array}$ & $\begin{array}{c}365 \\
(78.5 \%)\end{array}$ \\
\hline $30 \leq \mathrm{AMI}<50$ & $\begin{array}{c}8,577 \\
(70.9 \%)\end{array}$ & $\begin{array}{c}6,933 \\
(72.3 \%)\end{array}$ & $\begin{array}{c}2,317 \\
(68.7 \%)\end{array}$ & $\begin{array}{c}510 \\
(76.1 \%)\end{array}$ & $\begin{array}{c}1,204 \\
(65.1 \%)\end{array}$ & $\begin{array}{c}603 \\
(70.5 \%)\end{array}$ \\
\hline $50 \leq \mathrm{AMI}<80$ & $\begin{array}{c}13,700 \\
(59.3 \%)\end{array}$ & $\begin{array}{c}10,866 \\
(59.7 \%)\end{array}$ & $\begin{array}{c}3,320 \\
(58.9 \%)\end{array}$ & $\begin{array}{c}615 \\
(53.5 \%)\end{array}$ & $\begin{array}{c}1,765 \\
(61.3 \%)\end{array}$ & $\begin{array}{c}940 \\
(58.6 \%)\end{array}$ \\
\hline $80 \leq \mathrm{AMI}<100$ & $\begin{array}{c}7,952 \\
(46.9 \%)\end{array}$ & $\begin{array}{c}6,263 \\
(48.2 \%)\end{array}$ & $\begin{array}{c}1,899 \\
(44.0 \%)\end{array}$ & $\begin{array}{c}475 \\
(51.9 \%)\end{array}$ & $\begin{array}{c}890 \\
(41.3 \%)\end{array}$ & $\begin{array}{c}534 \\
(42.7 \%)\end{array}$ \\
\hline $100 \leq \mathrm{AMI}$ & $\begin{array}{c}16,820 \\
(16.1 \%)\end{array}$ & $(16.2 \%)$ & $\begin{array}{c}2,550 \\
(13.9 \%)\end{array}$ & $\begin{array}{c}725 \\
(12.4 \%)\end{array}$ & $\begin{array}{c}935 \\
(14.7 \%)\end{array}$ & $(14.6 \%)$ \\
\hline
\end{tabular}

Source: 2008-2012 CHAS

Table A.4. Cost-burdened renter households breakdown

\begin{tabular}{l|c|c|c|c|c|c}
\hline & Multnomah & Portland & Corridor & $\begin{array}{c}\text { Central } \\
\text { Eastside }\end{array}$ & $\begin{array}{c}\text { East } \\
\text { Portland }\end{array}$ & Gresham \\
\hline $\mathrm{AMI}<30$ & $\begin{array}{c}28,324 \\
(76.7 \%)\end{array}$ & $\begin{array}{c}23,722 \\
(75.2 \%)\end{array}$ & $\begin{array}{c}8,260 \\
(80.9 \%)\end{array}$ & $\begin{array}{c}2,060 \\
(77.6 \%)\end{array}$ & $\begin{array}{c}4,190 \\
(80.2 \%)\end{array}$ & $\begin{array}{c}2,010 \\
(86.5 \%)\end{array}$ \\
\hline $30 \leq \mathrm{AMI}<50$ & $\begin{array}{c}21,799 \\
(85.6 \%)\end{array}$ & $\begin{array}{c}17,391 \\
(85.7 \%)\end{array}$ & $\begin{array}{c}6,225 \\
(87.6 \%)\end{array}$ & $\begin{array}{c}1,420 \\
(91.6 \%)\end{array}$ & $\begin{array}{c}2,640 \\
(86.6 \%)\end{array}$ & $\begin{array}{c}2,165 \\
(86.4 \%)\end{array}$ \\
\hline $50 \leq \mathrm{AMI}<80$ & $\begin{array}{c}13,728 \\
(46.8 \%)\end{array}$ & $\begin{array}{c}11,432 \\
(48.8 \%)\end{array}$ & $\begin{array}{c}3,019 \\
(38.8 \%)\end{array}$ & $\begin{array}{c}945 \\
(43.9 \%)\end{array}$ & $\begin{array}{c}1,239 \\
(37.8 \%)\end{array}$ & $\begin{array}{c}835 \\
(35.5 \%)\end{array}$ \\
\hline $80 \leq \mathrm{AMI}<100$ & $\begin{array}{c}2,574 \\
(18.7 \%)\end{array}$ & $\begin{array}{c}2,176 \\
(19.5 \%)\end{array}$ & $\begin{array}{c}593 \\
(15.9 \%)\end{array}$ & $\begin{array}{c}215 \\
(17.3 \%)\end{array}$ & $\begin{array}{c}(14.4 \%) \\
(14 \%)\end{array}$ \\
\hline $100 \leq \mathrm{AMI}$ & $\begin{array}{c}1,642 \\
(5.1 \%)\end{array}$ & $(5.1 \%)$ & $(6.0 \%)$ & $(3.9 \%)$ & $\begin{array}{c}16 \% \\
(7.4 \%)\end{array}$ & $\begin{array}{c}115 \\
(6.6 \%)\end{array}$ \\
\hline
\end{tabular}

Source: 2008-2012 CHAS

When we break down cost burden by tenure status, the picture changes somewhat. Generally, owner-occupants (about 50\% of the residents on the corridor) are no more costburdened than the city as a whole. As we move east along the corridor, cost burdens lessen. 
Table A.5. The drilldown of multifamily buildings

\begin{tabular}{l|c|c|c|c|c|c}
\hline & Multnomah & Portland & Corridor & $\begin{array}{c}\text { Central } \\
\text { Eastside }\end{array}$ & $\begin{array}{c}\text { East } \\
\text { Portland }\end{array}$ & Gresham \\
\hline Duplex & $11.2 \%$ & $11.1 \%$ & $13.1 \%$ & $20.7 \%$ & $10.8 \%$ & $9.1 \%$ \\
\hline $3-4$ units & $16.1 \%$ & $15.1 \%$ & $23.3 \%$ & $22.5 \%$ & $24.5 \%$ & $22.2 \%$ \\
\hline 5 to 9 & $15.0 \%$ & $13.6 \%$ & $19.3 \%$ & $17.7 \%$ & $17.1 \%$ & $24.4 \%$ \\
\hline 10 to 19 & $14.1 \%$ & $13.4 \%$ & $15.2 \%$ & $18.1 \%$ & $13.7 \%$ & $14.7 \%$ \\
\hline 20 to 49 & $15.2 \%$ & $16.0 \%$ & $13.1 \%$ & $12.6 \%$ & $13.2 \%$ & $13.6 \%$ \\
\hline 50 or more & $28.4 \%$ & $30.7 \%$ & $16.1 \%$ & $8.4 \%$ & $20.8 \%$ & $16.0 \%$ \\
\hline Total HH & 326,952 & 267,514 & 61,789 & 17,643 & 30,595 & 13,551 \\
\hline
\end{tabular}

Data Source: ACS 2010-2014

\section{APPENDIX B: ADDITIONAL TRANSPORTATION DATA}

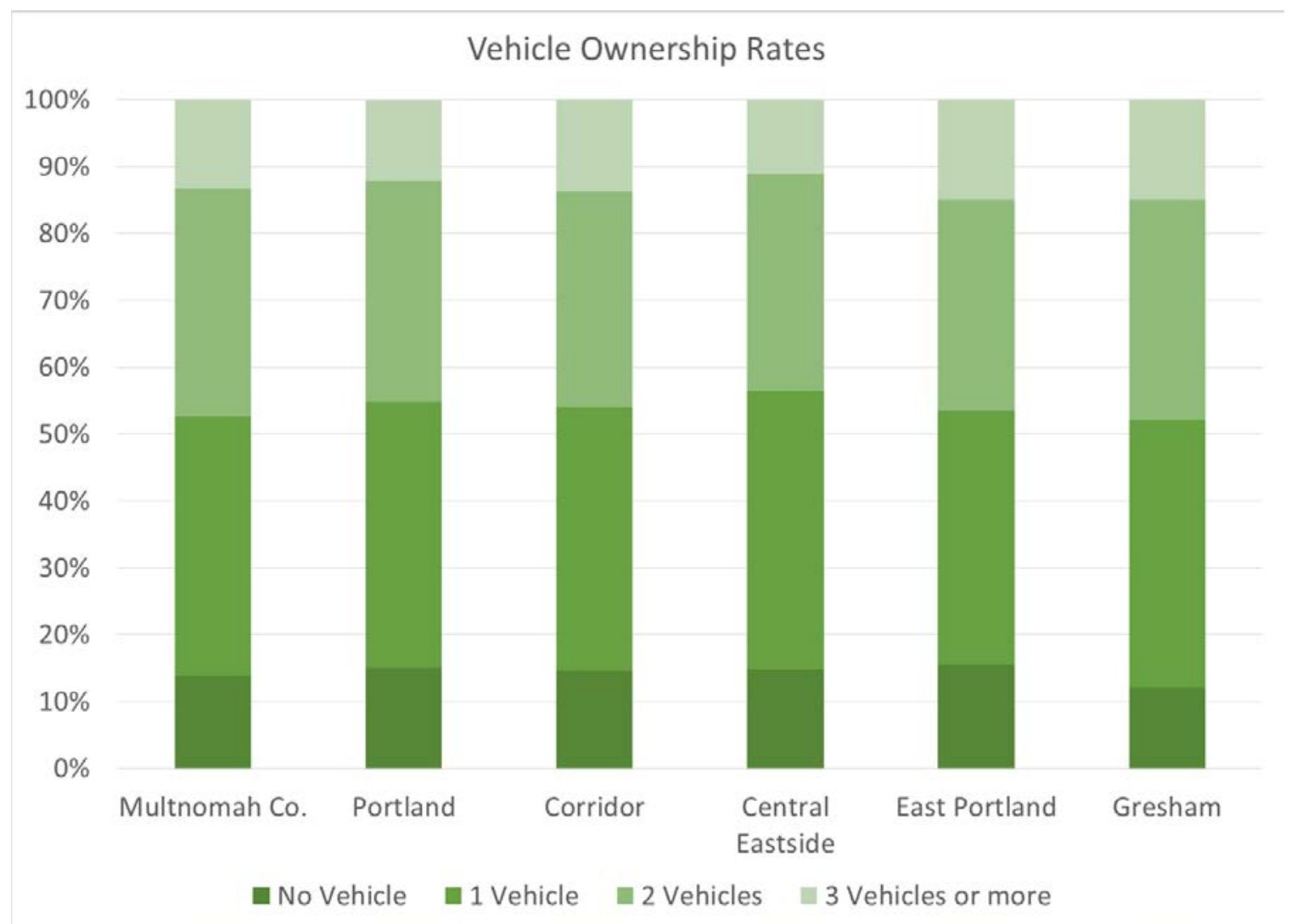

Figure B.1. Vehicle ownership rates along the corridor

Source: ACS 2010-2014 

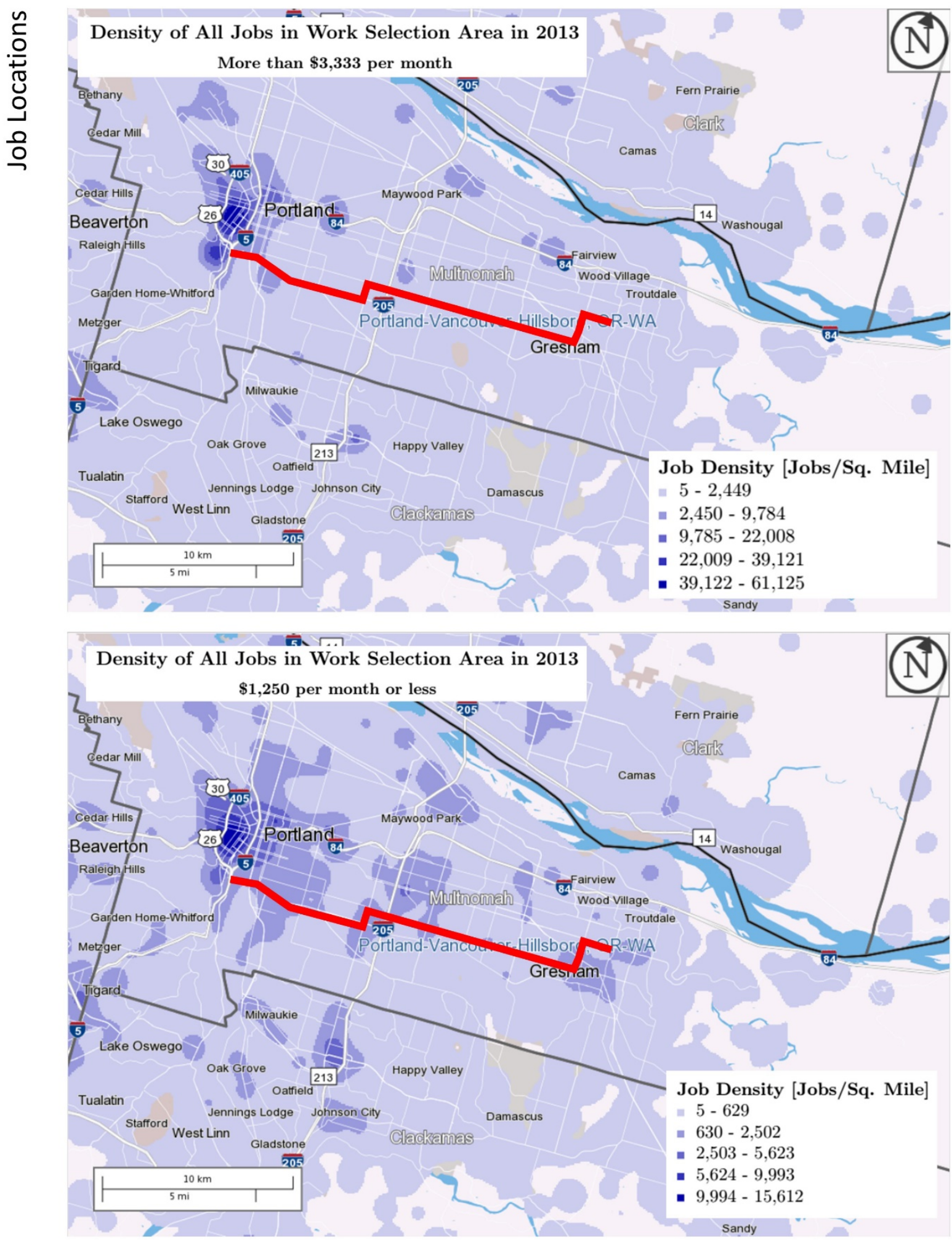

Source: U.S. Census Bureau - Longitudinal Household-Employment Dynamics - "On the Map" tool - onthemap.ces.census.gov

Figure B.2. Job locations for low- and high-income workers 

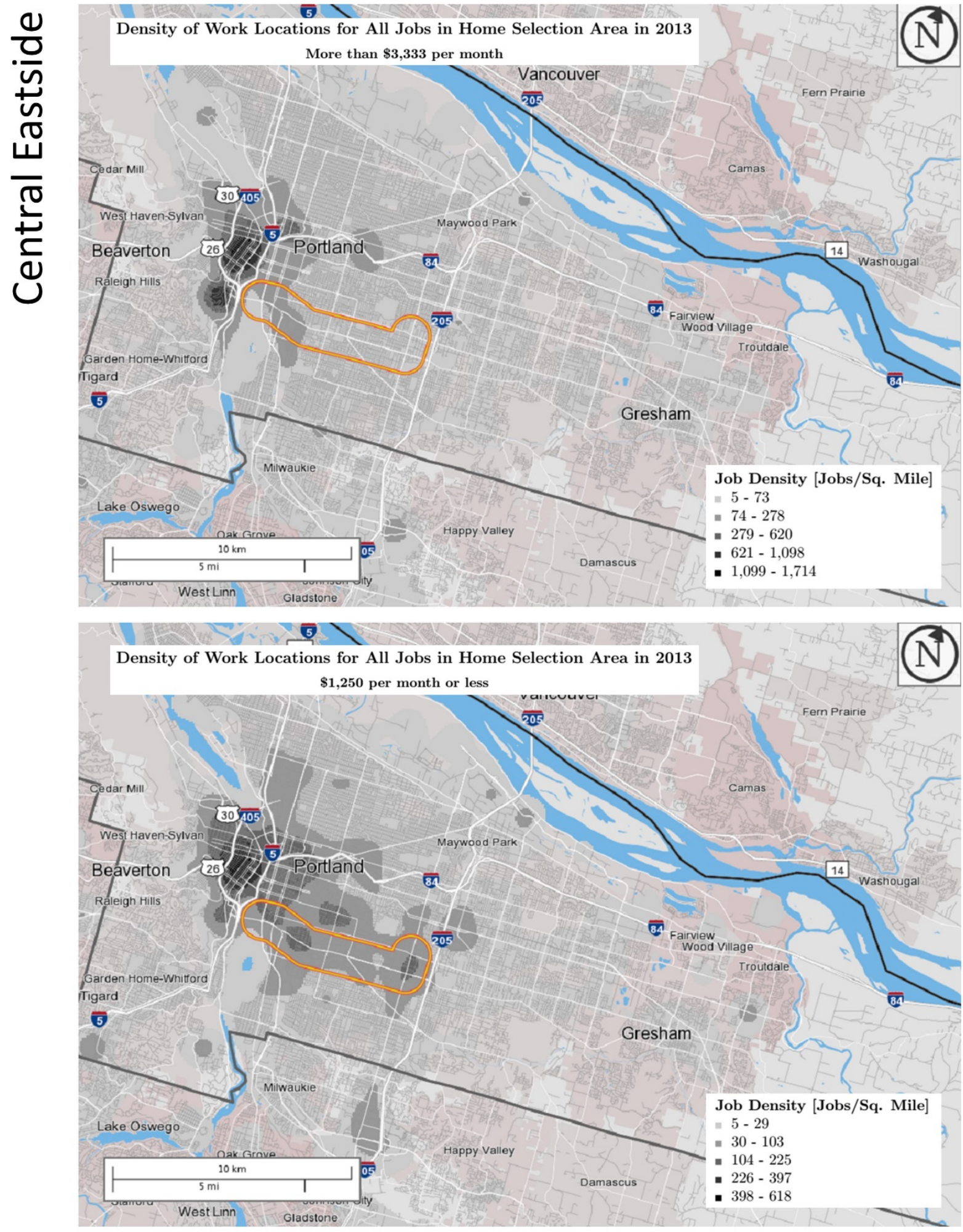

Source: U.S. Census Bureau - Longitudinal Household-Employment Dynamics - "On the Map" tool - onthemap.ces.census.gov

Figure B.3. Job locations for workers living in Central Eastside 

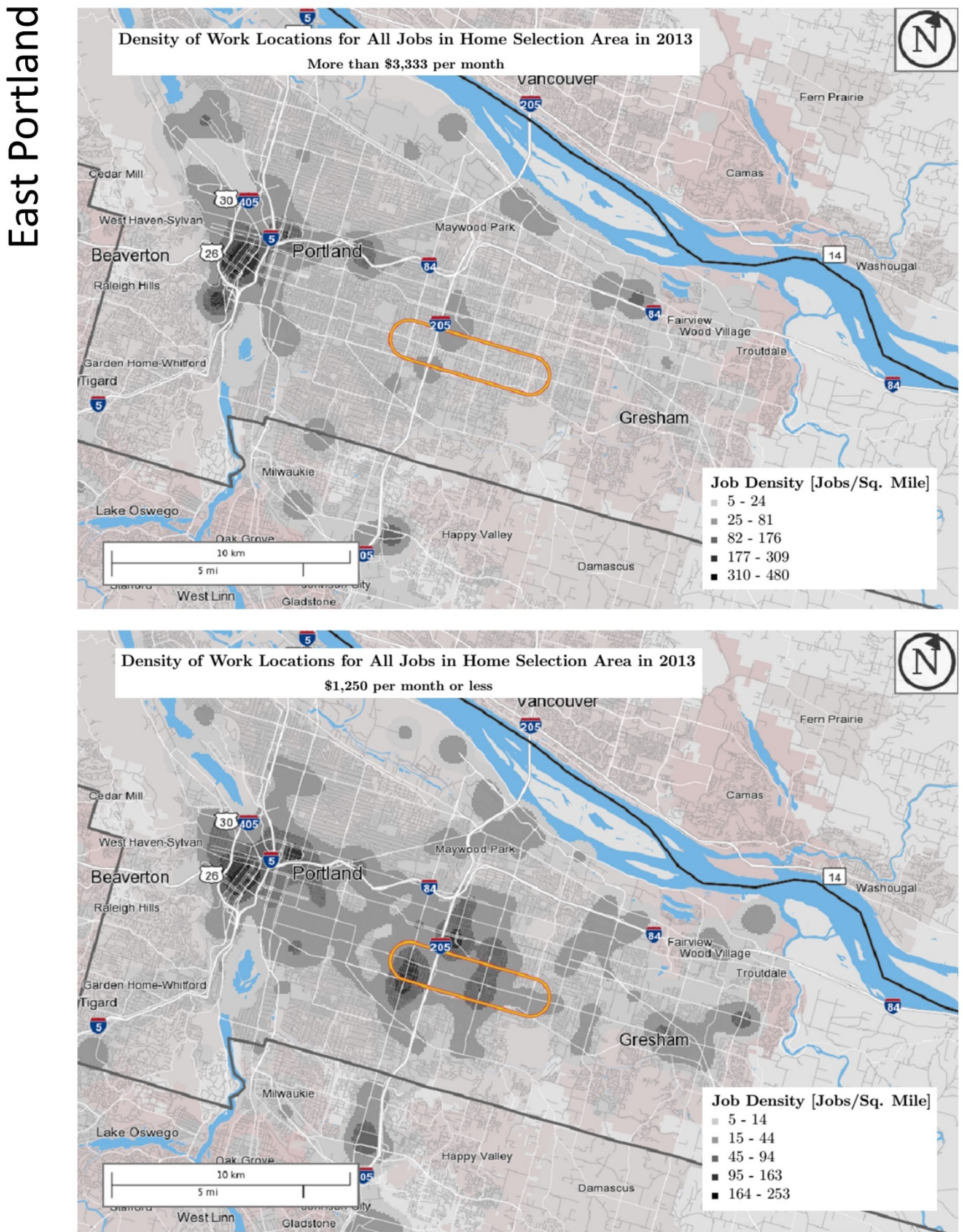

Source: U.S. Census Bureau - Longitudinal Household-Employment Dynamics - "On the Map" tool - onthemap.ces.census.gov

Figure B.4. Job locations for workers living in East Portland 

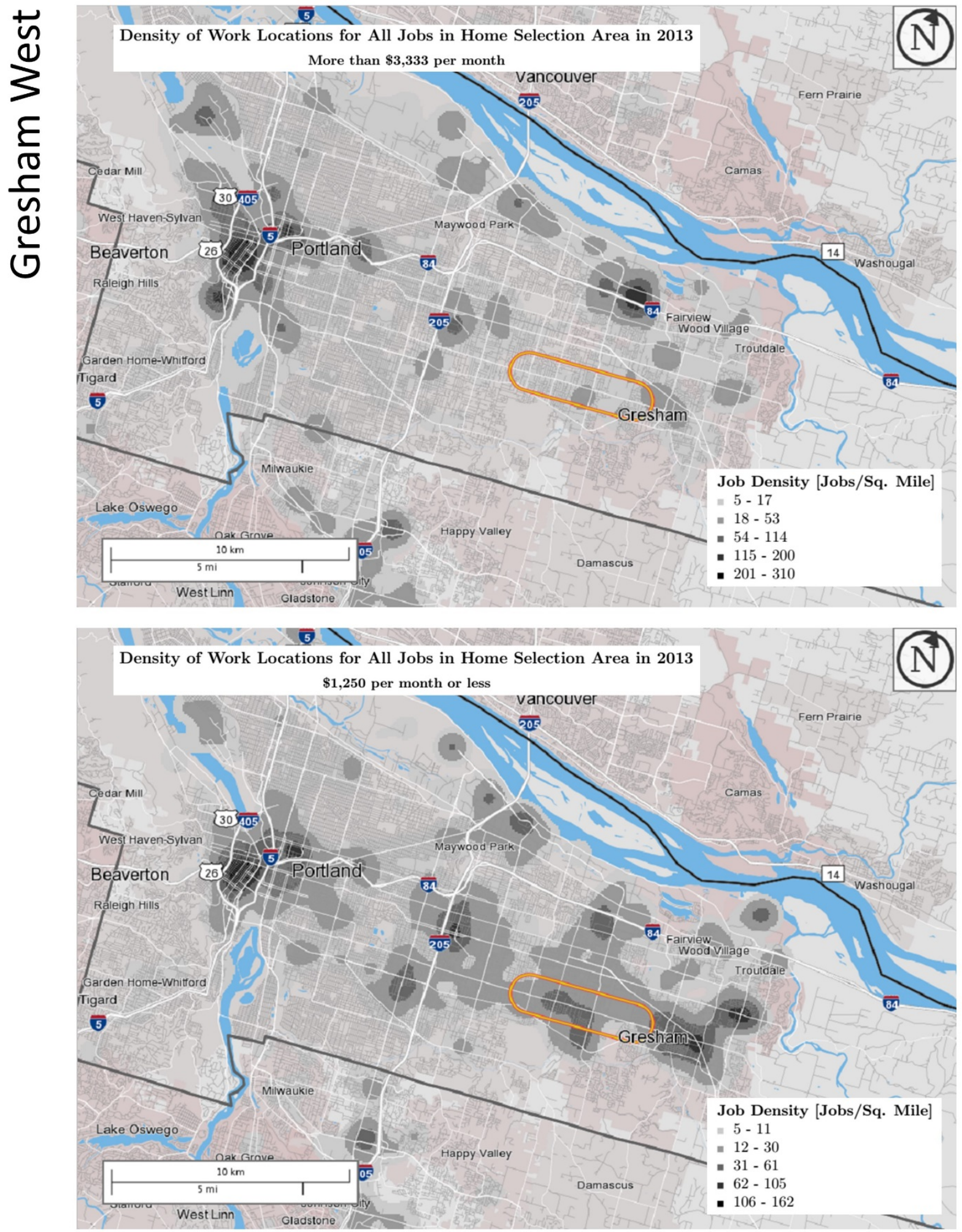

Source: U.S. Census Bureau - Longitudinal Household-Employment Dynamics - "On the Map" tool - onthemap.ces.census.gov

Figure B.5. Job locations of workers living in west Gresham 

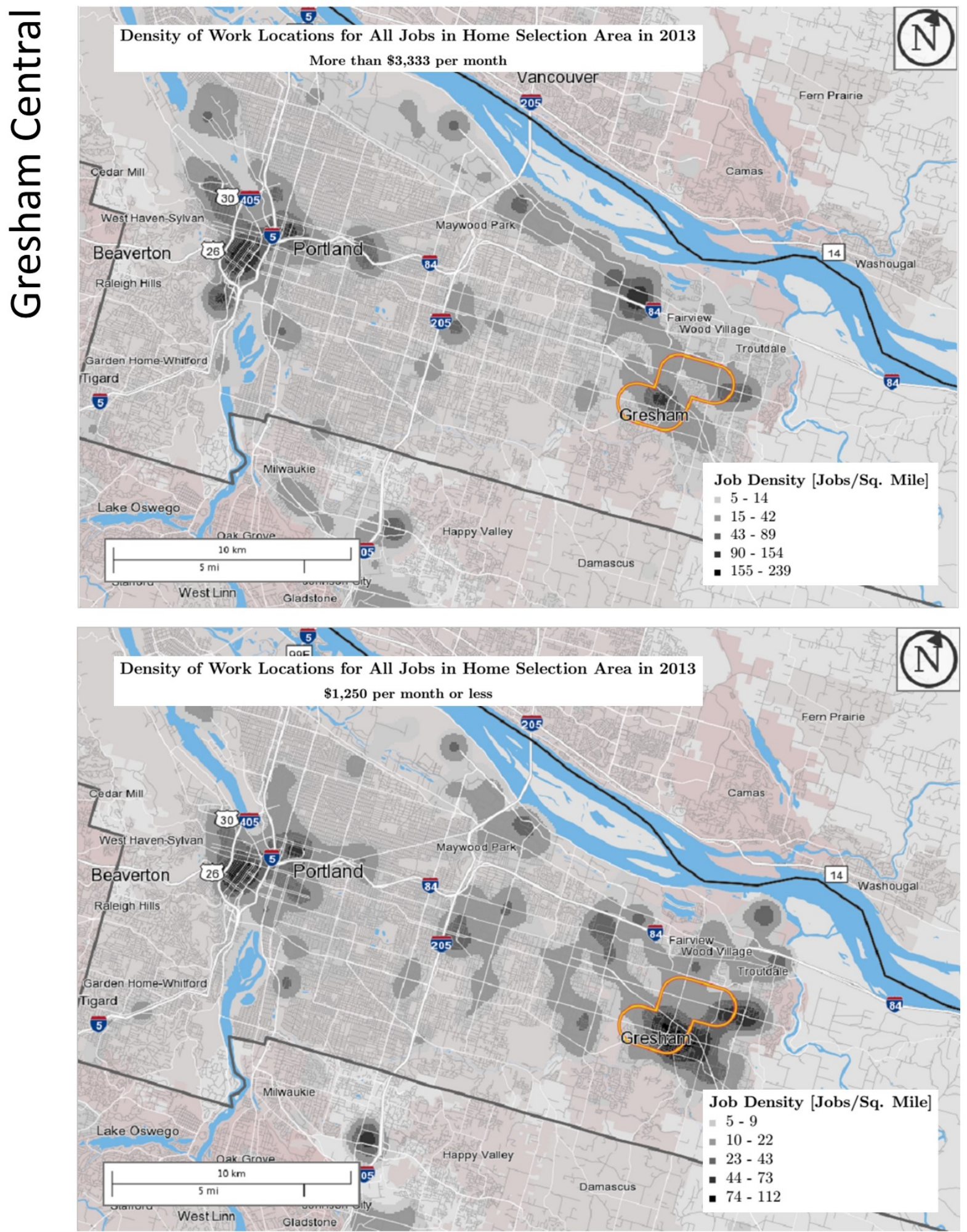

Source: U.S. Census Bureau - Longitudinal Household-Employment Dynamics - “On the Map” tool - onthemap.ces.census.gov

Figure B.6. Job locations of workers living in central Gresham 

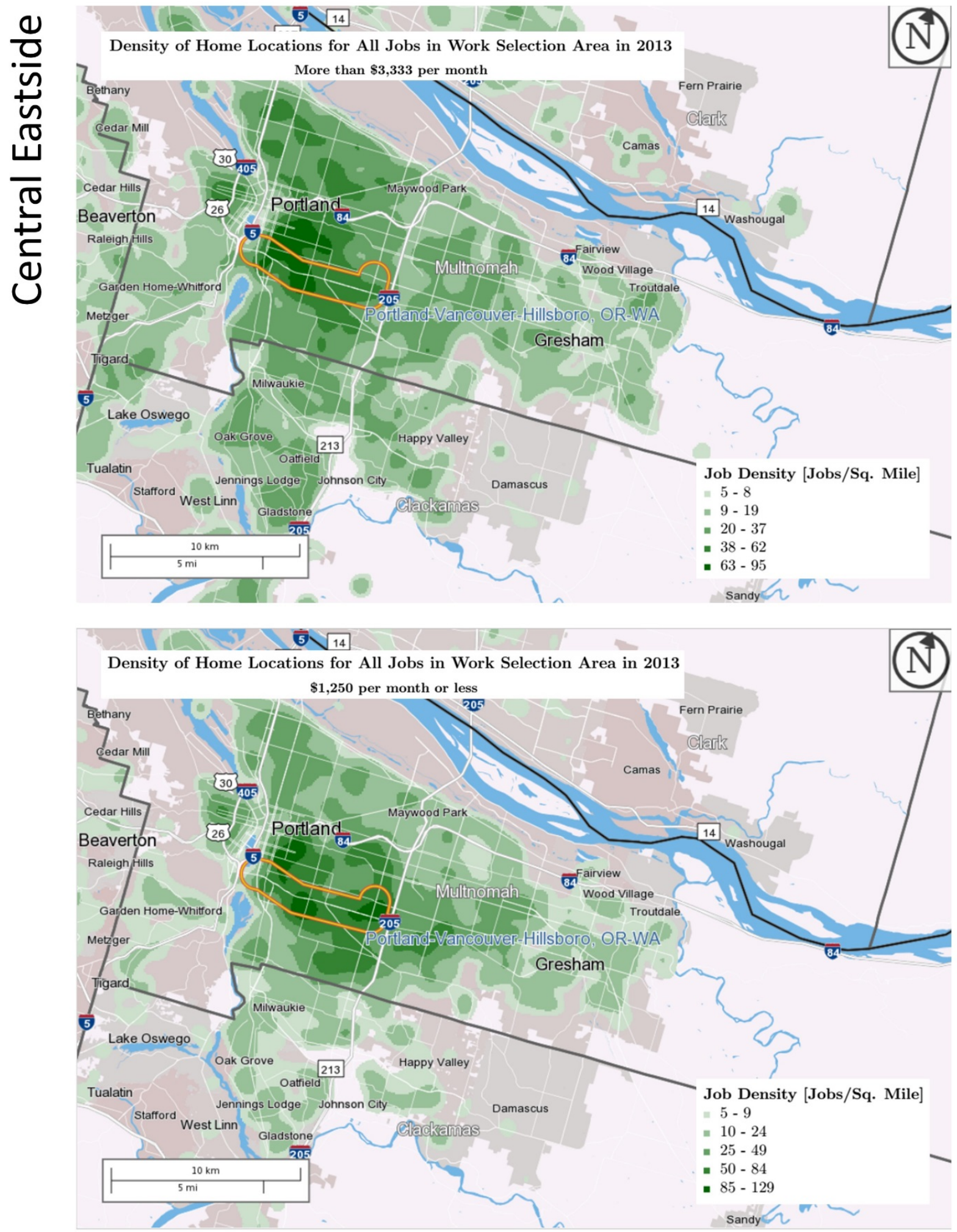

Source: U.S. Census Bureau - Longitudinal Household-Employment Dynamics - "On the Map” tool - onthemap.ces.census.gov

Figure B.7. Home locations of workers working in Central Eastside 

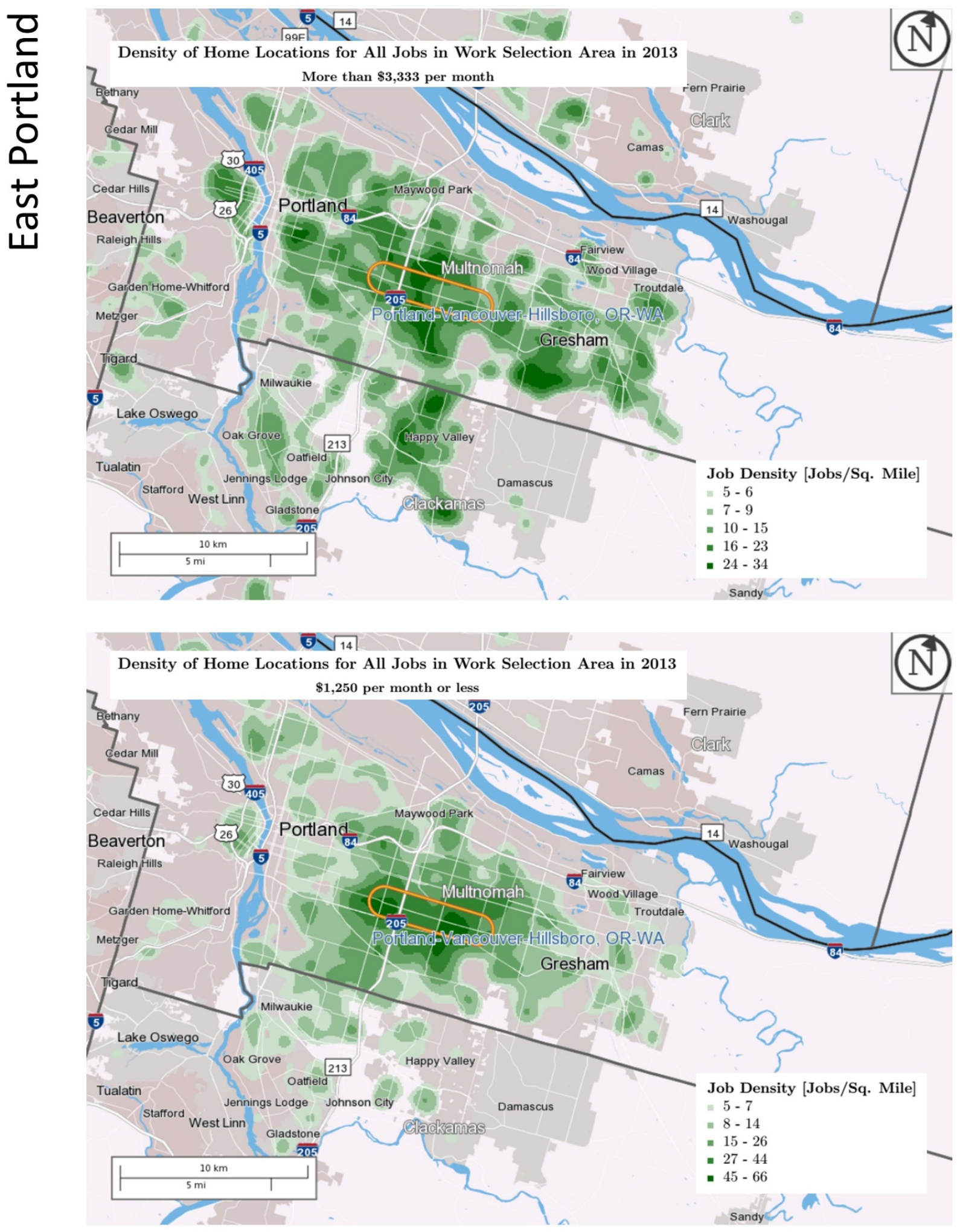

Source: U.S. Census Bureau - Longitudinal Household-Employment Dynamics - "On the Map" tool - onthemap.ces.census.gov

Figure B.8. Home locations of workers working in East Portland 

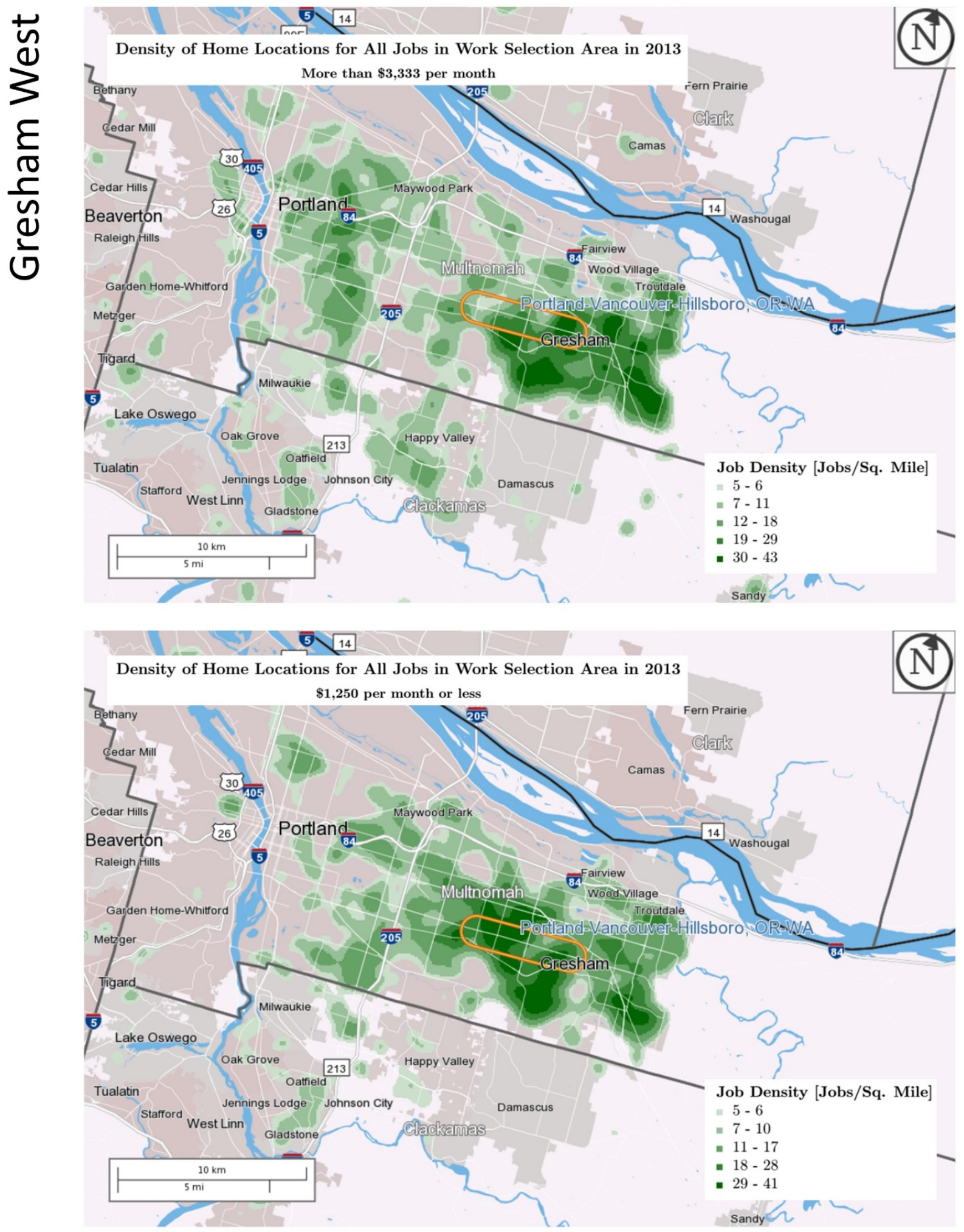

Source: U.S. Census Bureau - Longitudinal Household-Employment Dynamics - “On the Map” tool - onthemap.ces.census.gov

Figure B.9. Home locations of workers working in west Gresham 


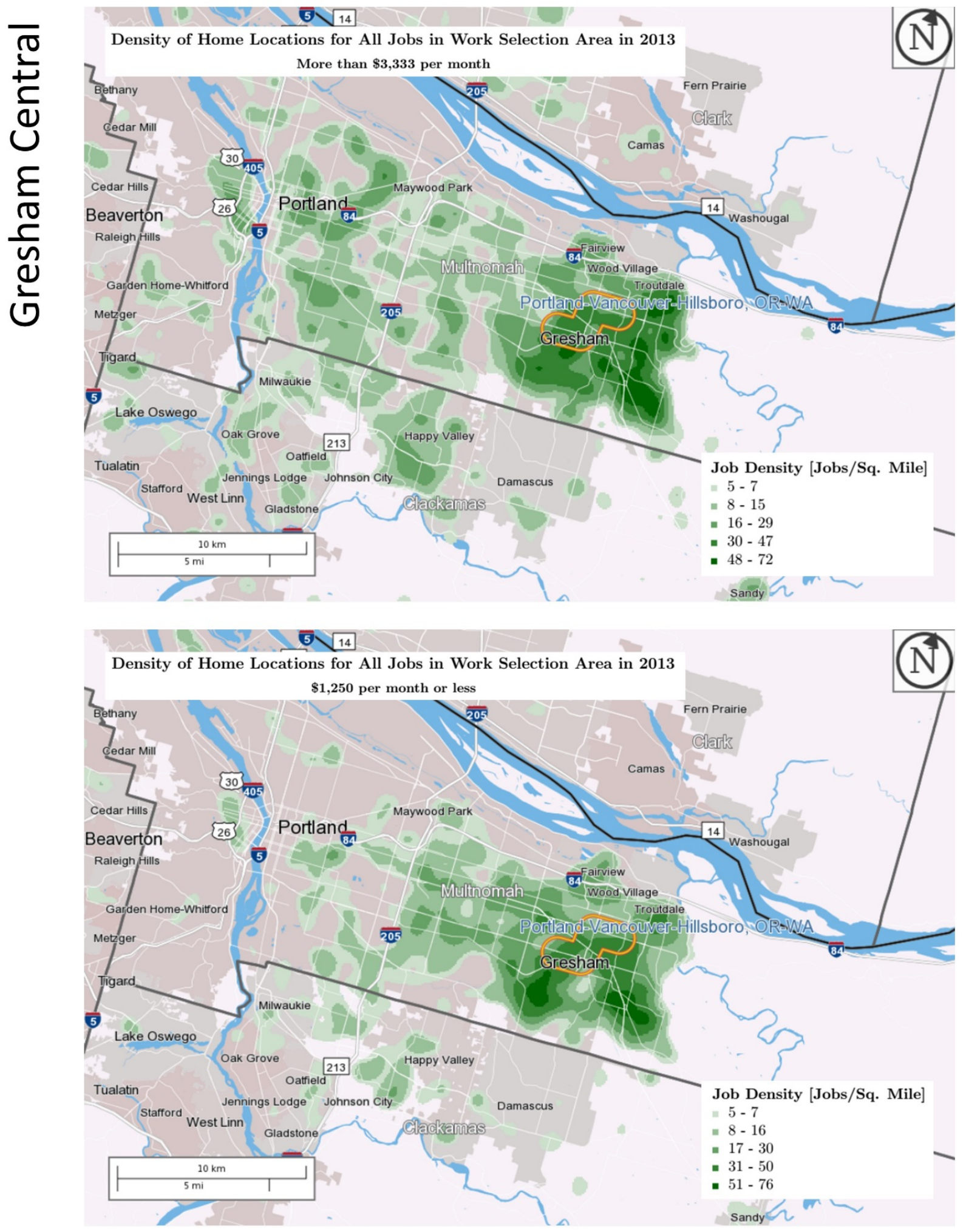

Source: U.S. Census Bureau - Longitudinal Household-Employment Dynamics - "On the Map" tool - onthemap.ces.census.gov

Figure B.10. Home locations of workers working in central Gresham 
Transportation Research and Education Center

Portland State University

1900 S.W. Fourth Ave., Suite 175

Portland, OR 97201 